Revista de la red interuniversitaria de estudios sobre las literaturas rioplatenses contemporáneas en Francia

17 | 2017

Hermetismo programático en la literatura rioplatense contemporánea (de 1980 a nuestros días)

\title{
Leyendo lo ilegible
}

\section{Craig Dworkin}

Bowling Green State University (ed.)

Translator. Valeria Grinberg Pla

\section{(2) OpenEdition}

1 Journals

\section{Electronic version}

URL: http://journals.openedition.org/lirico/3979

DOI: $10.4000 /$ lirico.3979

ISSN: 2262-8339

\section{Publisher}

Réseau interuniversitaire d'étude des littératures contemporaines du Río de la Plata

\section{Electronic reference}

Craig Dworkin, «Leyendo lo ilegible », Cuadernos LIRICO [En línea], 17 | 2017, Puesto en línea el 14 diciembre 2017, consultado el 21 abril 2019. URL : http://journals.openedition.org/lirico/3979 ; DOI : 10.4000/lirico.3979

This text was automatically generated on 21 April 2019

\section{(c) (i) (3) $\Theta$}

Cuadernos LIRICO está distribuido bajo una Licencia Creative Commons Atribución-NoComercialSinDerivar 4.0 Internacional. 


\section{Leyendo lo ilegible}

\section{Craig Dworkin}

Bowling Green State University (ed.)

Translation : Valeria Grinberg Pla

\section{EDITOR'S NOTE}

En nombre de Cuadernos LIRICO agradecemos el acuerdo del autor para publicar esta traducción. El original en inglés es el primer capítulo del libro de Craig Dworkin: Reading the Illegible. Evanston: Northwestern University Press, 2003. Las notas de traducción se incluyen entre corchetes.

Je rêvais croisades, voyages de découvertes dont on n'a pas de relations, républiques sans histoires, guerres de religion étouffées, révolutions de mœurs, déplacement de races et de continents: je croyais à tous les enchantements.

Arthur Rimbaud

In dreams begin responsibilities.

William Butler Yeats

\section{Formalismo radical}

\section{Mil amapolas}

1 Entre las ensoñaciones nocturnas de la poesía, la forma de la vanguardia ha retornado al sueño de la política. Quiero comenzar despertándonos dentro -y no fuera- de ese sueño. Pero deberíamos estar lúcidos en nuestro soñar, porque las discusiones de política literaria suelen tropezar precisamente con el tipo de confusiones gramaticales contra el cual alerta Ludwig Wittgenstein. Esta confusión es exacerbada por la restricción común de la «política » a un referente tan limitado que la reduce a la pregunta de "por quién votaste ». Por consiguiente, este tipo de circunscripción va en desmedro del significado de la política, y evita convenientemente las responsabilidades más rigurosas, continuas y autocríticas de una vida política plena y genuina. La « política » en su sentido más amplio incluiría todas las relaciones de poder, sin importar cuán locales o minúsculas sean, y la 
ética de su distribución. En este sentido, lo « político » se extiende no sólo a lo personal, como nos lo recuerda el lema de toda una generación de teóricas feministas, sino a los más ínfimos datos de la vida cotidiana. Desde cierta perspectiva, esos datos bien pueden parecer de pequeña envergadura (después de todo, es sólo un poema), pero nunca son baladíes; no sólo son coextensivos con una que otra organización de poder, no importa cuán global, sino que tienen además -en y por sí mismos- igual plenipotencia. «En resumen, todo es política, pero toda política es a la vez macropolítica y micropolítica $»^{1}$. Pasar por alto la política de tales detalles como meras trivialidades, amenaza con dejar los mismos desequilibrios de poder que uno querría rectificar en gran parte sin examinar y mucho más profunda -e insidiosamente- afianzados. Peor aún, el desdén por los detalles en la honrada persecusión de asuntos «más grandiosos» corre el riesgo de, por ese medio, implicarlo a uno en la misma política a la cual los propios objetivos buscarían oponerse. Cómo mínimo, una negligencia de este tipo renuncia a la abundante vigilancia que las cuestiones políticas tanto demandan. «Buena o mala, la política y sus juicios siempre son molares, pero es lo molecular, con sus apreciaciones, quien la 'hace' $»^{2}$. Por consiguiente, la política de la literatura no es menos tensa. En el sentido estrecho de la "política ", los poemas no son eficaces, así de simple. En el mejor de los casos, quizás presenten modelos a partir de los cuales los lectores puedan extrapolar modos de pensar o de comportamiento, los cuales a su vez pueden ser traducidos a otros contextos y sistemas. En la medida en que los poemas afectan la comprensión del lenguaje del lector, tienen el potencial de alterar todas aquellas relaciones extraliterarias que también involucran el lenguaje; pero no tienen influencia directa en la política electoral, ni alimentan a los hambrientos, ni suavizan los golpes. Si quieres organizar un sindicato, digamos, no escribes un poema: sales a la calle y organizas. George Oppen es un modelo ejemplar. Más aún, los análisis políticos de la literatura con frecuencia dan dos pasos que terminan siendo reaccionarios: primero, plantean la pregunta en el sentido estrecho $\mathrm{y}$, al encontrar después que la literatura es insuficiente, descartan toda pregunta sobre política literaria, manteniendo un status quo en el cual los aspectos significativos y apropiados de la política literaria siguen sin ser examinados ${ }^{3}$. El peligro de tomar a la poesía como políticamente eficaz en el sentido estrecho, no es tanto una ingenuidad con respecto a lo que la poesía no puede hacer, sino más bien una falta de atención a aquello que sí puede hacer.

2 De hecho, la importancia misma de las cuestiones políticas exige un entrenamiento más sofisticado de la lectura. Tanto Jed Rasula como Bruce Andrews han sugerido los requisitos de este tipo de lectura y, teniendo en cuenta las similitudes entre sus planteamientos y el mío, vale la pena repasar aquí brevemente los puntos principales de sus posiciones. Según la terminología de Rasula (y a riesgo de sonar como Henry James), se puede diferenciar entre la política por medio del, la política en y la política del poema ${ }^{4}$. La política por medio del poema sería, por consiguiente, política en un sentido estrecho: esencialmente pistas falsas, aunque, tal vez, ocasional y colateralmente exitosas en ciertas canciones de protesta o en los ornamentos poéticos que acompañan los discursos. La política en el poema se referiría a la discusión de Mussolini en Pound, digamos, o a las temáticas feministas de Adrienne Rich. En el capítulo $4^{5}$, voy a ocuparme de los peligros de enfocarse en la política en el poema y de la inadecuado de poner fin al análisis político a ese nivel sin considerar la política del poema: lo que es significado por su forma, puesto en acción por sus estructuras, está implícito en su filosofía del lenguaje; cómo posiciona a sus lectores; y una serie de preguntas concernientes al poema como objeto material - 
cómo fue producido, distribuido e intercambiado-. O, en los términos de Bruce Andrews: « la escritura como política, no la escritura sobre política ».

3 Entonces, quiero recalcar que lo que sigue es, por un lado, mucho más modesto que la mayoría de las discusiones de la política del arte -no se pretende tratar asuntos de estado, ni se extraen sutilezas temáticas de historias sobre relaciones sociales- $y$, por otro, mucho más escrupuloso. Extender la propia lectura a la política del poema es prerrequisito para una lectura más significativa y plenamente política o ética, y con ese fin, a lo largo de todo el libro quiero poner el énfasis en un formalismo radical. Estoy adaptando el término de la definición de Andrews de una "praxis radical», la cual « incluye los rigores de una celebración formal, una infidelidad lúdica, una cierta ilegibilidad dentro de lo legible: un modo de tender hacia lo infinito, una abierta exuberancia, una máquina en perpetuo movimiento, una transgresión $»^{7}$. Un formalismo suficientemente radical persigue el más estrecho de los 'close readings' al servicio de cuestiones políticas, en lugar de para excluirlas. Al mismo tiempo, se niega a considerar el poema como una esfera separada de la política, incluso al enfocarse en el « poema mismo ». Simple y sencillamente es cuestión de ser fiel a la forma. En tanto investigación patafísica de los datos ínfimos, los formalismos radicales labran en lo concreto; en donde « concreto » es aquello de lo que está hecha la calle.

Para poder elaborar una exposición más matizada de estas afirmaciones, quiero dirigir la atención de este capítulo hacia la Internationale situationniste (IS). Los situacionistas no sólo se esforzaron por desarrollar teoría y práctica de una actividad micropolítica extensiva a todos los aspectos de la vida cotidiana (incluyendo el poético), sino que también concibieron esa actividad explícitamente en términos lingüísticos y literarios. Más aún, se dieron cuenta de que incluso los experimentos más utópicos tendrían que ser llevados a cabo -como la poesía más radicalmente experimental- dentro de ciertos parámetros inevitables y estructuras preexistentes. Su teoría resultante sobre el détournement ofrece una clara explicación de la fuerza ideológica detrás de la apropiación y el «mal uso » estratégico de fuentes textuales, típicos para las obras que discuto a lo largo de este libro. De hecho, los situacionistas ofrecen una analogía histórica y conceptual con respecto a los impulsos revolucionarios, que generalmente no han sido tan bien articulados en el discurso político en torno a la poesía y al arte angloamericanos discutidos en otros capítulos. $\mathrm{Si}$, al final, los situacionistas no respondieron de manera conclusiva las preguntas que se hicieron sobre la viabilidad de la poesía política, sus provocaciones hicieron visible de manera palpable la ausencia de esas aspiraciones en otros campos, y además han sido la base de varios impulsos que sí intentaron llegar a alguna respuesta, empezando por las mismas preguntas de los situacionistas, pero siguiendo trayectorias de vuelo menos prominentes. De hecho, el raconto situacionista bien puede racionalizar de un modo demasiado astringente el aspecto distintivamente irrestricto de la ilegibilidad poética, no obstante lo cual más le vale mostrar que, dado el sueño de la política, una poesía que no aspire a cierto grado de ilegibilidad sería una pesadilla. Una precaución, sin embargo: lo que sigue será, en sí mismo, una desviación del pensamiento situacionista. Más un bricolaje que un intento de presentar una historia exhaustiva o partisana, este capítulo extraerá ciertos momentos valorables de la larga, cambiante y problemática trayectoria de la teoría situacionista y, tal vez, es más fiel a su espíritu justamente en aquellos puntos en donde los mismos situacionistas hubieran estado más que dispuestos a denunciarla y rechazarla. "Les hallucinations sont innombrables. C'est bien ce que j'ai toujours eu: plus de foi en l'histoire, l'oubli des 
principes. Je m'en tairai: poètes et visionnaires seraient jaloux » [Las alucinaciones son innumerables. Es lo que siempre tuve: falta de fe en la historia, olvido de los principios. Me callaré: poetas y visionarios sentirían celos de mí] $]^{8}$.

\section{Gangland y filosofía}

El arte de vivir presupone (...) que la vida como un todo -la vida cotidiana- debería convertirse en una obra de arte.

Henri Lefebvre

La belleza será convulsiva, o no será.

André Breton

5 «Se han de multiplicar los asuntos y los objetos poéticos», proclamaba en 1957 el «Informe sobre la construcción de situaciones » de Guy Debord y, por consiguiente, con la inevitabilidad más improbable, dentro del entorno de la izquierda existencialista de la Europa de mediados de siglo, convergieron varias tradiciones artísticas y políticas en la Internationale Situationniste. Desde cierta perspectiva, obtuvo su lugar en la historia del anaquismo y del marxismo herético. En la tradición de las revoluciones de Kiel (1918), Turín (1920), Kronstadt (1921), y Cataluña, la IS combinaba la autogestión individual con la violencia colectiva frente a la autoridad, rechanzando tanto los modelos capitalistas como marxistas, en favor de soviets radicalmente antiautoritarios y autónomos. Más aún, este modelo de soviet, con su autogestión en continua disolusión y reconstitución, debía ser aplicado a la vida cotidiana en la forma de «situaciones construidas »: reacciones ad hoc, específicas, creativas, y consensuadas ante las demandas de un entorno de pequeños colectivos transitorios de personas espontáneamente creados. 0 , en la jerga situacionista: «Un moment de la vie, concrètement et délibérément construit par l'organisation collective d'une ambiance unitaire et d'un jeu d'événements » [Un momento de la vida, construido concreta y deliberadamente por medio de la organización colectiva de un ambiente unitario y de un juego de acontecimientos.] En pocas palabas, la trayectoria del pensamiento situacionista emparentada con la filosofía política de Proudhon, Bakunin y Luxemburgo -con inflecciones a partir de los argumentos de Lukács, del grupo en torno a Socialisme ou barbarie, y (de modo altamente significativo) de Henri Lefebvre- pero con correcciones hechas debido a la influencia ideosincrática de escritores como Fourier, Sade, Saint-Just, y Bataille ${ }^{9}$. Al mismo tiempo, es heredera del legado de un número de escritores que predicaban una poesía de crítica social: Lautréamont (Isidore Ducasse), Alfred Jarry, Arthur Rimbaud, Arthur Craven, y los surrealistas que también siguieron su iniciativa $^{10}$.

6 En efecto, desde otra perspectiva, la IS marca el ciclo de la vida media del futurismo, que decaería en el dadaísmo y luego en el surrealismo. En 1956, un congreso en el laboratorio de Giuseppe Pinot Gallizio en Alba recogió los fragmentos de la disolución centrífuga del surrealismo; entre otros, reunió a miembros del grupo escandinavo de Asger Jorn: CoBrA (Copenague-Bruselas-Amsterdam) y su encarnación como Mouvement International pour une Bauhaus Imaginiste o MIBI (incluyendo a Constant Niewenhuys y Jørgen Nash), al grupo alemán Spur, al Movimento Nucleare (Enrico Baj), al « London Psychogeographical Committee » de Ralph Rumney y a Gil Wolman, quien representaba a la Internationale Lettriste. Este último grupo, que incluía al teórico urbanista Iván Chtcheglob, era una escisión reciente de los lettristes de Jean-Isidore Isou. Cuando tuvo lugar el congreso fundador de 1957 en Cosio d'Arroscia, que fusionó oficialmente a todas estas organizaciones en la Internationale situationniste, los letristas -incluyendo a Guy-Ernest 
Debord y Michèle Bernstein- jugaron un rol clave, y estos dos se mantuvieron como figuras centrales de la IS, junto a otros participantes notables, incluyendo a Attila Kotányi, Jacqueline de Jong, Jeppesen Martin, René Riesel, y su cronista René-Donatien Viénet $^{11}$. Antes de su disolución oficial en 1972, alrededor de setenta miembros desfilaron por la IS, aunque en todo momento su núcleo se mantuvo reducido a un puñado por medio de un estricto ostracismo y de habituales renuncias. Las purgas fueron inmediatas (Baj fue excluido ni bien llegó a Alba y varios de los miembros fundadores del MIBI fueron descartados a los pocos meses del congreso de Cosio d'Arroscia), y las exclusiones se sucedieron regularmente a lo largo de los años, dado que Debord imitaba las prácticas de Isou y Breton en la cima de su fervor sectario. De hecho, como con las crónicas del dadaísmo, el surrealismo y el letrismo, la vigilancia mezquina y recurrente de la membresía oficial situacionista y la catalogación interminable de las expulsiones son tediosas y avergonzantes. En el mejor de los casos, es la cara poco feliz de la moneda juvenil con la que se compra la energía de tales movimientos y, en el peor, del autoritarismo sintomático de incluso los provocadores mejor intencionados.

7 Aunque la convención fundadora de la IS tuvo lugar en 1957, los situacionistas llamaron la atención sólo una década después, cuando la sección local de la Union National des Étudiants Français de la Universidad de Estrasburgo, durante la resistencia a la autoridad administrativa de 1966, se acercó a ellos en busca de inspiración. Después de consultar a los situacionistas, el centro de estudiantes de Estrasburgo publicó De la misère en milieu étudiant (De la miseria en el medio estudiantil) de Mustapha Khayati y, con la belleza de un suicidio dadá, intentó su propia disolución como organismo burocrático. Las dos declaraciones situacionistas más importantes datan de 1967: la publicación de La société du spectacle (La sociedad del espectáculo) de Guy Debord y Traité de savoir-vivre à l'usage des jeunes générations (Tratado del saber vivir para uso de las jóvenes generaciones) de Raoul Vaneigem. Esta pareja complementaria de manifiestos representa -tanto en lo estílistico como en lo conceptual-, el Tractatus y las Investigaciones del movimiento, respectivamente. Sin embargo, después de los juicios y la atención mediática de Estrasburgo, la reputación situacionista se debió menos a estas publicaciones que a la propagación de la agitación estudiantil hacia París, y a la revolución de mayo del 68, cuando los situacionistas se unieron a les enragés de Nanterre, poniendo en práctica teorías que iban a influir en pensadores que van desde Michel de Certeau, Maurice Blanchot y Jean Beaudrillard hasta la hueste de grupos «pro-situ » angloamericanos que siguieron sus pasos ${ }^{12}$.

8 Mucho de lo que inspiró a los herederos del legado situacionista puede encontrarse en La société du spectacle de Debord. Por más de varias décadas de actividad revolucionaria, Debord fue sorprendentemente consistente en sus argumentos, en parte porque sus juicios tempranos resultaron tan proféticos. En efecto, dichos juicios todavía son incisivos treinta años después de la escritura de La société, porque el mundo que describe se ha vuelto cada vez más familiar ${ }^{13}$. La société du spectacle sintetiza y condensa el meollo de las teorías de Debord en una prosa lapidaria, pulida en 221 tesis numeradas. Con un trazo amargo y agudo « comme l'eau-forte sur le fer » [como el aguafuerte sobre el hierro], La société du spectacle describe la desolación de una cultura de posguerra en la cual el capital ha colonizado completamente los más triviales aspectos de la vida cotidiana que sólo una revolución igual de total de dicha vida puede ahora tener la esperanza de ofrecer alguna resistencia. ${ }^{14} \mathrm{O}$, en los términos afines al concepto de Baudrillard de "revolución total ", articulado pocos años después de la publicación de La société: « Les signes doivent brûler 
eux aussi » [Los signos también deben ser quemados $]^{15}$. Con una argumentación paralela a la vinculación deconstructiva del valor de cambio y el valor de uso de Baudrillard -en la cual el uno emerge como categoría disfrazada del otro, según una relación peligrosamente suplementaria-, Debord diagnostica el modo en el cual la lógica del capital ha llegado a dominar y orquestar la esfera del consumo, tal y como previamente sólo había gobernado la producción. Mientras antes, imagina con nostalgia, vivíamos en una época en donde el tiempo ajeno al trabajo transcurría genuinamente fuera de las demandas del capital y más allá de su mirada panóptica -cuando, en pocas palabras, "nadie estaba mirando »-, ahora ya no hay ninguna parte del día, por más ostensiblemente "privada " que sea (e incluyendo la manera misma de entender el tiempo), que escape a las demandas del capital. También el tiempo libre y el tiempo de descanso han sido co-optados hasta el punto de que no hay un sólo momento del día, como diría William Blake, que Satán no pueda encontrar.

Esa permeabilidad satánica es la condición del « espectáculo ». Debord frustra cualquier reificación fácil del término al evitar cuidadosamente una definición única; de hecho, una prescripción semejante sería en sí misma característica de la inclinación natural del espectáculo por la estabilidad y su tendencia a congelar, fijar y anquilosar ${ }^{16}$. De manera consecuente, en la escritura de Debord, el espectáculo no es la mera «industria del espectáculo" (una de las denotaciones de la palabra en francés), ni tampoco es simplemente los medios visuales y la publicidad, y ni siquiera es necesariamente visual aunque nada de esto queda fuera de su ámbito y todos estos aspectos han sido específicamente incluidos en el transcurso de la argumentación de Debord ${ }^{17}$-. Entonces, si en un apartado el espectáculo es definido como « capital acumulado hasta el punto en que se convierte en imagen ", es igualmente "falsa conciencia del tiempo " y una "relación social entre personas» mediada a través de la imagen ${ }^{18}$. Es decir, el concepto de espectáculo de Debord mantiene una "semejanza familiar »: carece de una definición única, pero se compone de una gama de condiciones descriptivas. No obstante la diversidad de registros de los referentes del espectáculo, algunas de sus características emergen con claridad a lo largo de La société. El espectáculo corresponde a una univocidad autoritaria que fomenta la recepción pasiva y el consumo obediente de su mensaje. Siendo lo « opuesto al diálogo », el espectáculo es un «monólogo » que no quiere saber nada de interrupciones o presentaciones alternativas ${ }^{19}$. Es más, en contra de la producción activa que desalienta, el espectáculo mantiene una esfera de reproducción pasiva; como "el sol que nunca se pone en el imperio de la modernidad pasiva", el espectáculo aspira a convertir a su espectador en un ser «pasivo», "sumiso » $\mathrm{y}$ 《 no pensante $»^{20}$.

Dado que dichas relaciones espectaculares se han extendido de la esfera de la producción a la del consumo, Debord proyecta su resistencia al espectáculo con un enfoque correspondiente, dirigiendo su atención hacia esta última con el escrutinio crítico tradicionalmente reservado para la primera ${ }^{21}$. Retomando una línea de Das Kapital, Debord afirma que un "producto, pese a estar listo para su consumo inmediato, no puede sin embargo servir de materia prima para otro producto $»^{22}$. En consecuencia, en lugar de separar a los consumidores de los productores, Debord aboga por una igualación desjerarquizada de ambos. Oponiéndose al monólogo del espectáculo, Debord reclama una "comunicación de doble sentido", en la cual los consumidores se convertirían en productores (desalienados) de sentido en su interacción con las mercancías, incluyendo el espacio y tiempo mercantilizados ${ }^{23}$. Estos diálogos serían necesariamente 
antiespectaculares, en parte porque evitarían la lógica reflectante del espejo (speculum). El diálogo productivo no refleja, para Debord, estructuras heredadas de autoridad, precisamente porque genera significación sin apelar a modelos previos o protocolos habituales. En tanto "situaciones construidas», estos diálogos, por definición, han surgido espontáneamente en el momento, de manera contingente e imprevista, a partir del material a mano. El situacionista es, en este sentido, un bricoleur que se las ingenia con tácticas ad hoc y rehúye estrategias predeterminadas o heredadas ${ }^{24}$. 0 , en los términos elaborados por Gilles Deleuze y Félix Guattari, los situacionistas practicaron el arte de la continua desterritorialización. Construyendo incluso el mundo espectacular que nos ha sido impuesto como " un espacio móvil de juego ", Debord propone que, como no tenemos otra opción más que seguir la corriente en cierta medida, al menos podemos introducir «variaciones libremente escogidas en las reglas del juego ${ }^{25}$. Evitando las reacciones aprendidas de memoria que ciertos códigos y estructuras disparan, semejante reestructuración lúdica de las « reglas del juego » ayuda a desestabilizar el autoritarismo implícito en las respuestas disciplinadas y las jerarquías que estas imponen. La «libre construcción » de estas situaciones define, según Debord, la " auténtica poesía » y con ese propósito aboga por un modo activo, lúdico, creativo y obstinadamente consciente de interactuar con mercancías en formas distintas a las prescriptas por la « maquinaria del consumo permitido $»^{26}$. Semejante "mal uso» de mercancías, códigos y entornos, instituye una « actividad creadora liberada » que Debord y los situacionistas consideran la «verdadera comunicación » ${ }^{27}$.

11 Estas figuras de la «comunicación» y de la «poesía» no son casuales, Debord frecuentemente moldea sus argumentos en pro de una resistencia política en términos de la práctica comunicativa y artística. En términos lingüísticos, el espectáculo corresponde a los modelos convencionales de la comunicación como "conducto", en los cuales un emisor (para usar los términos de Jakobson) construye y transmite un mensaje a un destinatario receptor. $\mathrm{O}$, para traducir esta jerarquía a un modelo literario: los escritores producen textos que los lectores luego consumen. La « comunicación verdadera», en el sentido de Debord, perturba estas jerarquías con un anarquismo de producción mutua que lleva al diálogo entre el lector y el escritor a un nivel de interacción tal, que la distinción misma entre ambos desaparece; los lectores típicamente pasivos se vuelven «a la vez productores y consumidores », mientras se ve cómo « escribir » $\mathrm{y}$ « leer » declinan hacia el mismo verbo ${ }^{28}$. Debord trabaja hacia una «definición de la comprensión como algo distinto del consumo. (Distinto pues). Entonces es politizante: una lectura radical encarnada en la escritura. Una escritura que es en sí misma 'lectura indómita' pide una lectura indómita ${ }^{29}$. Jean-Marie Apostolidès relaciona este aspecto de la crítica de Debord con los surrealistas, invocando el concepto de Pierre Bourdieu de « un champ nouveau » [un campo nuevo] que es "de l'imaginaire », « expérimental », y en donde «l'incitation n'y est plus de recevoir les œuvres passivement, mais de les produire pour élargir le champ d'expérience individuel » [la incitación ya no es recibir las obras pasivamente, sino producirlas para expandir el campo de experiencia individual $]^{30}$. Vasos comunicantes. En donde « vaso » es un verbo.

12 En efecto, la actividad desafiante de las palabras cuando se niegan a ser meros contenedores de la comunicación instrumental es la piedra de toque de la poética situacionista, y porque « las palabras coexisten con el poder en una relación análoga a la que el proletariado (...) puede mantener con el poder ", su resistencia es tanto un modelo de actividad política como una versión de una escritura políticamente activa ${ }^{31}$. A lo largo 
de este libro veremos ejemplos de un lenguaje activo, y si bien no voy a insistir sobre este punto, la fuerza política de su ejemplo no debe ser olvidada. Pese a que, en el análisis de Debord, « las palabras trabajan por cuenta de la organización dominante de la vida », no son meros indicadores de «señales indiscutibles» en un intercambio de información, porque no son en sí mismas "informacionistas " ${ }^{32}$. Este aspecto antisemántico del lenguaje será examinado con más detalle en el capítulo 3, pero cuando el lenguaje excede su autoridad comunicativa -en esos momentos cuando su utilidad familiar y saturada tartamudea para revelar su naturaleza « radicalmente extraña » y foránea- uno capta los destellos de "la insumisión de las palabras »3.

En efecto, vale la pena considerar la cuestión de una lingüística situacionista insumisa. Si la revolución situacionista debe extenderse a « todos los aspectos » de la vida y negarse a seguir « combatiendo la alienación por medio de formas alienadas de lucha », ¿qué hacer con la esfera textual, en la cual « la palabra escrita » siempre ha sido « el arma principal de los soberanos »? ${ }^{34}$ Obviamente, toda lectura implica hasta cierto grado una producción de significación por parte del lector; el punto es que, con demasiada frecuencia, dicha producción es rutinaria y está disciplinada por protocolos preestablecidos e inflexibles. Por otro lado, el texto « indeterminado » tampoco es garantía de un diálogo debordiano. Incluso aquellas obras que fomentan o exigen una participación creativa por parte del lector pueden operar de acuerdo con jerarquías y control manipulativo; en efecto, esa manipulación es frecuentemente mucho más insidiosa dada su ulterioridad. En ambos casos, la fuerza de la respuesta de los situacionistas está en su énfasis en el mal uso creativo de códigos establecidos, estructuras existentes, y condiciones ineludibles. Cuando ese principio de la actividad revolucionaria es traducido al lenguaje y a la literatura, constituye una "paragramática». En la definición de Leon Roudiez, toda estrategia de lectura que desafíe la gramática referencial normativa de un texto al crear « redes de significación innaccesibles por medio de hábitos de lectura convencionales » es paragramática $^{35}$. Los capítulos subsiguientes sopesan una serie de estrategias paragramáticas -desde lecturas que ignoran los límites entre palabras o seleccionan y vuelven a combinar ciertas letras de las palabras en lugar de tenerlas en cuenta en el orden convencional, hasta lecturas que proceden en sentido vertical, hacia abajo de la página, en lugar de horizontalmente, de izquierda a derecha. Antes de dirigir la atención a los ejemplos de paragramática propios de los situacionistas, quiero enfatizar la apuesta política de tales actividades que llevan la acción revolucionaria al campo de la literatura $\mathrm{y}$, en definitiva, al lenguaje mismo.

\section{Coups de dés}

La insubordinación de las palabras (...) ha demostrado que la crítica teórica del mundo del poder es inseparable de una práctica que lo destruye.

Mustapha Khayati

El aspecto lúdico del diálogo de los situacionistas con el mundo a su alrededor no debería eclipsar el imperativo con el cual juguetonamente usaron mal los objetos encontrados. Debord y sus compatriotas comprendieron que todo juego era una apuesta en contra de un opositor que siempre iba a estar un turno más adelantado. En consecuencia, sus análisis tienen en cuenta el destino de hacer oposición en un mundo tan profundamente colonizado por las estructuras capitalistas modernas, que los actos de resistencia no sólo son anticipados sino que han sido incorporados de entrada como parte integral de la estrategia del capital. En el escenario moderno, las embestidas más inauditas de las 
vanguardias políticas y artísticas ya no son meramente reprimidas, o ignoradas, o incluso asimiladas, tanto como son transformadas -de acuerdo con un ciclo de recuperación cada vez más rápido- en tácticas al servicio de los mismos poderes que originalmente tenían intención de atacar. Pero " l'avant-garde », como sabía Asger Jorn, « se rend pas » [no se rinde]. Ya sea en la calle o en las páginas de un libro, nos encontramos con códigos y estructuras que heredamos, habitamos y no podemos simplemente rechazar. Estas donées, sin embargo, no significan que la situación, por más funesta, sea completamente irremediable, y los situacionistas ofrecen tácticas para jugar precisamente en tales circunstancias. En efecto, parte de la fuerza de los muchos laberintos que se disparan a lo largo de las páginas de los textos situacionistas reside en su representación de estructuras en las cuales uno está atrapado y perdido sin remedio; si los situacionistas ya no intentan salir de estos atolladeros, es porque reconocen que el único escape consiste en transformar la geografía en la cual uno ya está (siempre) atrapado. Si el Minotauro, el animal totémico del surrealismo, ya no puede ser simplemente exterminado, o evitado, bien puede ser desvié con una diestra verónica -con ese destello de la bandera rojinegra que flameó sobre París en el verano de $19688^{-36}$.

Por medio de la elaboración y de ejemplos de semejantes desvíos [détournements], Debord aporta un modelo para la interacción productiva con formas dadas e inevitables. Détourner , «desviar » en francés, es el verbo usado para describir desvíos ilícitos: malversación, apropiación indebida, secuestro. En el léxico situacionista, esta palabra se convirtió en un terme de métier abreviado para la frase "détournement des éléments esthétiques préfabriqués » [desvío de elementos estéticos prefabricados]. Antítesis de la cita, que marca y reinscribe la autoridad, el détournement persigue una poética del plagio en la tradición de Lautréamont, cuyo infame silogismo proclama: «Les idées s'améliorent. Le sens des mots y participe. Le plagiat est nécessaire, le progrès l'implique » [Las ideas se mejoran. El sentido de las palabras es partícipe. El plagio es necesario, el progreso lo implica $]^{37}$. Tomando lo dado y mejorándolo, el détournement perturba las jerarquías al iniciar un diálogo en un contexto previamente monológico y al inscribir múltiples autores y múltiples lugares en la producción de significado. Para mantener ese diálogo y evitar que simplemente vuelva a convertirse en otro monólogo, tanto los elementos prefabricados [ready-made] como su manipulación deben ser evidentes. En lugar de llevar a cabo una mera cancelación o negación, el détournement obedece, por tanto, a una lógica paralela a la del collage modernista, en el cual los elementos mantienen una referencia simultánea a sus contextos originales, los cuales nunca son borrados del todo, y también a la nueva composición del collage en la que han sido introducidos ${ }^{38}$. Por lo tanto, cada elemento del collage, como escribe el Grupo $\mu$, « lleva necesariamente a una doble lectura: una lectura del fragmento visto en relación con su texto de origen, y una lectura del mismo fragmento incorporado a una totalidad nueva, diferente $»^{39}$. Más aún, dentro de esa nueva totalidad, los elementos del collage -como los de un objet détourné- siempre mantienen una cierta autonomía, resistiéndose a ser subsumidos el uno por el otro; « en el collage », como nota Marjorie Perloff, « la jerarquía cede el lugar a la parataxis $»^{40}$.

En donde el collage simplemente puede reconocer la conjunción de elementos provenientes de diferentes registros, el détournement se enfoca, no obstante, en la deformación de esos registros y en la frustración de sus conclusiones aparentemente naturales; re-construye objetos y eventos en sus propios términos, pero en contra de sus fines ostensibles, poniendo a los códigos de los elementos apropiados en contra de sí mismos. En pocas palabras, el détournement es una forma de comunicación que contiene su 
propia crítica. Puesto que esta crítica interrumpe el fluido funcionar de las ideologías, dejando al descubierto estructuras y lógicas aparentemente naturales, que de otro modo serían dadas por sentado, y las emplea luego en formas sorprendentes y novedosas, los desvíos situacionistas son frecuentemente ПРИЕМЫ ОстРАНЕНИЯ (artefactos de extrañamiento). En palabras de la clásica definición de Shklovski de dichos artefactos, es decir détournements, estos sirven para hacernos " percibir que la piedra es piedra »-y así poder arrojarla contra la vidriera de una tienda o a un furgón policial en la calle GayLussac $^{41}$ - . Como decía un grafiti de mayo del 68, cuando la escritura se explayaba por las paredes de la Sorbonne y de Les Halles como concreción del sueño de Lautréamont de una poesía que algún día sea escrita por todos: « Sous les pavés, la plage » [Bajo los adoquines, la playa ${ }^{42}$.

Al reestructurar el paisaje urbano, el grafiti puede ser, en efecto, la instancia más familiar del détournement. En su forma más simple, un grafiti puede convertir el signo impasible del poder corporativo -por ejemplo, la sólida extensión de una pared incomunicadora- en el sostén de una proclama de, justamente, aquellas voces que estaría excluyendo. Más aún, dependiendo del contexto, el efecto puede ser más pronunciado. En mi barrio de West Berkeley, por ejemplo, un grupo de "vándalos veganos ", como los llamaron los periódicos, estuvo activo a principios de los noventa. Una de sus intervenciones, de manera estratégica, tapaba letras en un cartel publicitario de yogur; contra un fondo de gente sonriente y saludable haciendo ejercicio, el original rezaba « Good Fast Food [buena comida rápida] ». Desvié rezaba: « Goo Fat od » [sobredosis (de) menjunje graso]. Un grupo diferente (presumo) usó la misma táctica para desvier, cerca de ahí, un anuncio muncipal que había sido colocado fuera de una licorería como parte de una campaña en contra de conducir bajo los efectos del alcohol. Originalmente, el anuncio decía «DUI: you can't afford it » [Alcohol: no te puedes permitir conducir bajo su influencia]; haciendo un juego de palabras con el nombre de la empresa automotriz, ahora el anuncio dice « DUI: you can ford it » [Conducir bajo la influencia (del alcohol): con ford tú puedes]. Como la poesía de mayo del 68, este grafiti pro situ sigue una genealogía extrañamente proléptica: ha sido inscrito en la ciudad siguiendo principios desarrollados por artistas, quienes fueron, ellos mismos, originalmente inspirados por grafitis urbanos anónimos. Les lettristes (François Dufrêne, Maurice Lamaître) y les nouveaux realistes (Mimmo Rotella, Raymond Hains, Jacques Villéglé), por ejemplo, habían estado trabajando " au pied du mur » [al pie del muro] desde comienzos de los años cincuenta -despegando fragmentos de afiches rasgados y recontextualizándolos en formas que evocaban las fotografías de Brassaï de mediados de siglo, de anuncios y grafitis parisinos estetizados y reorganizados.

Uno de los artistas que trabajó seriamente con esos afiches callejeros déchirés fue Asger Jorn, y en su pintura L'avant-garde se rend pas de 1962 hace referencia explícita al grafiti, e implícita en su Paris by Night de $1959^{43}$. Ya he señalado el rol central que Jorn jugó en la fundación de la Internationale Situationniste, y quiero considerar su peinture détourné [pintura desviada], la cual provee una buena ilustración de la estética situacionista. Exhibida como un conjunto de «modifications » en 1959, expuesta en 1962 con una serie subsiguiente de "nouvelles défigurations » [nuevas desfiguraciones], fueron construidas por medio de reelaboraciones de pinturas de escenas kitsch de tiendas de segunda mano $\mathrm{e}$ imitiaciones de arte. Jorn recubría con sus abstracciones netamente chorreadas y su primivismo gestual, toscamente figurativo, los retratos y paisajes realistas que conseguía de segunda mano. En parte, las desfiguraciones de Jorn son la respuesta vanguardista, típicamente hostil y escandalosa, ante los emblemas de la « tradición » artística, haciendo 
gala de la irreverencia, pero no siempre del buen humor irónico con el cual Duchamp sugirió, en La boite verte, usar un Rembrand como tabla de planchar. En muchos de sus retratos desviés, sin embargo, tales como Fraternité avant tout y Les deux pingouins, la fuerza de esos gestos revela también la agresión de la respuesta de Jorn frente a la petulancia inalterable de la " alta sociedad " y la imagen de autosatisfacción que la haute bourgeoisie tiene de sí misma. No por casualidad, en los términos de Débord, esa imagen refleja es la definición misma del espectáculo; así como la mercancía espectacular « se contempla a sí misma en un mundo de su propia manufactura ", del mismo modo, a través del reflejo del espectáculo, «el orden imperante diserta indefinidamente sobre sí mismo en un monólogo ininterrumpido de autoalabanzas. El espectáculo es el autorretrato del poder ", que se convierte en un «ininterrumpido discurso sobre sí mismo, un monólogo laudatorio " y narcisista ${ }^{44}$.

La irreverencia con la cual las desfiguraciones de Jorn quebrantan el zumbido de dicho monólogo es sin duda gratificante, pero sus détournements van más allá de una simple burla o negación del original. A diferencia de L.H.O.O.Q. de Duchamp, al cual obviamente alude, L'avant-garde se rend pas, por ejemplo, no es tanto un acto de desfiguración, como la reorientación de una imagen que originalmente habría provocado el tipo de significación trillada que acompaña a una respuesta habitual (« linda niñita », digamos), que vuelve tales emblemas prácticamente invisibles. En parte, la diferencia entre Duchamp y Jorn jugando al barbero es un efecto de la diferencia entre un ícono único de las bellas artes y una pintura anónima. En el détournement de Jorn, sin embargo, incluso el pigmento sucio y amarronado, agregado al busto de la figura, ha sido aplicado con cierta delicadeza refinada, equiparable al cuidado con el cual le ha dibujado el vello facial; estos gestos están en evidente contraste con las letras desprolijas y las figuras infantiles que la rodean. Más aún, al sugerir que esas figuras fueron garabateadas en la pared por la niña misma, Jorn revitaliza la inmovilidad de la escena original con un sentido narrativo, generando una gama de nuevas significaciones a partir de la tensión entre la pintura original y su détournement. La sonrisa cortésmente neutral e impasible de la niña adopta un tono impío, y su mirada directa, tal vez incluso ingénue en su origen, adquiere una cierta impertinencia desafiante, al igual que la remilgada pose con las manos recatada y pasivamente por delante. "¿Quién, yo?» parece negar su pose con falsa inocencia. En efecto, la cuerda de saltar sostenida con esas manos es emblemática; por un lado, signo del juego infantil, la corde à sauter (cuerda de saltar; ça saute aux yeux [es evidente]) no puede, por el otro lado, anular completamente la confesión susurrada de que su juego ha trop tirée sur la corde (ido demasiado lejos).

La misma combinación de impudicia y abnegación colorea también los garabateos pueriles del propio Jorn, los cuales conllevan un cierto grado de desmentido. Aunque la diferencia entre marcar la reproducción fotográfica de una pintura y marcar irrevocablemente la superficie de la pintura misma no es intrascendente, más que recrearla de manera efectiva, Jorn cita la audacia de Duchamp. ${ }^{45}$ Originalmente, L.H.O.O.Q. también fue un acto de остРАНЕНИя, aunque le haya llegado el turno de volverse familiar; Debord no fue el único en notar que «les moustaches de la Joconde ne présentent aucun caractère plus intéressant que la première version de cette peinture " [los bigotes de la Gioconda no presentan ningún rasgo más interesante que la primera versión de esta pintura]. ${ }^{46}$ El détournement de Jorn adquiere interés porque se extiende no sólo a la pintura encontrada, sino también a los bigotes de Duchamp: reorientando su finalidad original y dándoles nuevos usos, de modo de que puedan ser vistos 
significativamente otra vez. Debido a la rapidez con la cual los gestos más desafiantes son recuperados -siendo un buen ejemplo, el estatus de alta cultura de las proclamas anti-arte dadás- la revolución efectiva debe ser contínua, motivo por el cual, precisamente, l'avantgarde se rend pas. Con este fin, uno no debería, obviamente, ver los détournements de Jorn como objetos acabados para ser leídos como pinturas tradicionales; estos registran su propia interacción con una pintura y deberían incitar los détournements subsiguientes a sus propios desvíos. De manera consecuente, el estatus implicado pero no integrado de los elementos originales y desviés en las pinturas de Jorn -su «diálogo » en términos de Debord- ayuda a prevenir la caída de su obra en una estasis fácilmente asimilable; Jorn mantiene a ambos lo suficientemente apartados como para que la nueva obra alterne constantemente entre sus elementos originales y su desviación, sacando chispas como un cilindro entre los dos polos de un dínamo. En L'avant-garde se rend pas, esa tensión es mantenida en gran parte por medio de la estructura recursivamente homóloga de la pintura: el garabateo ilícito de Jorn es una mise en abîme en la escena implicada de los garabateos ilícitos propios de la niña.

21 Jorn negocia una ambivalencia igualmente irresoluble en su desfiguración de 1962, Les deux pingouins (Los dos pingüinos), la cual nuevamente subraya la diferencia entre su obra y la pintura original, al mismo tiempo que las conecta, acercándolas lo suficiente como para involucrarlas en un diálogo significativo. Aunque muchos de los títulos de Jorn no pasan de ser más que calambures poco inspirados -Le barbare et la berbère (El bárbaro y la berebe), o La vie d'une nature morte (La vida de una naturaleza muerta), por ejemplo,- muchas veces merecen atención ${ }^{47}$. Un título como Arbre arbitraire (Árbol arbitrario), por ejemplo, evoca muy bien la famosa ilustración de Saussure en el Cours de linguistique général y subraya precisamente el modo en el que la naturaleza arbitraria e inmotivada del signo puede ser re-motivada para que arbitraire pueda, de hecho, generar arbitraire. "Siempre me decido por un título que tenga el máximo número posible de significados, pero que sea aplicable solamente a un único objeto", señala Jorn, y vale la pena considerar "les deux pingouins » más allá de su obvia referencia ${ }^{48}$. A cierto nivel, Jorn insiste meramente en el humor inherente al retrato original: un hombre encorsetado en su traje formal, de "pingüino", y viéndose -como lo hace un pingüino- "à la fois guindé et comique [estirado y cómico a la vez] ». ¿Pero por qué solamente « deux » pingüinos, cuando en cada panel aparece una imagen duplicada de modo que realmente hay cuatro pingüinos visibles en la pintura? Resulta que la respuesta está al alcance de la mano. A diferencia del inglés [y del español], el francés tiene en verdad dos « pingüinos »; por fuera de los textos ornitológicos, pingouin y manchot son usados de manera prácticamente intercambiable. Más aún, Jorn alude a este otro pingüino al dejar una de las manos del hombre manifiestamente visible, mientras que sus brazos han sido oscurecidos y acortados para asemejarse, a grandes trazos, a unas alas. "Un manchot » denota también un hombre manco, y describiría no sólo la figura en la pintura, sino también la condición del mismo Jorn, al trabajar con óleos como medio, lo cual requiere de un solo brazo, a diferencia de la cerámica, que requiere de ambas manos, y a la que Jorn le dedicaba la otra parte de su tiempo artístico. La mano en un pájaro, en otras palabras, vale más que dos volando ${ }^{49}$. $\mathrm{Si}$ la propia "mano » de Jorn es visible en las chorreaduras y figuraciones rápidamente trabajadas de esta pintura, nunca borra por completo la mano realista que estuvo « avant» [antes] ahí (como está inscrito en el primer panel del díptico). Desde un punto de vista idiomático, il n'est pas manchot denota " es bueno con las manos", y esta es precisamente la distinción que separa la pintura gestual de Jorn, con su estudiado 
primitivismo, de las más o menos torpes [awkward] (¿o son torpavícolas [aukward]?) técnicas de sus fuentes de tiendas de segunda mano.

Por lo tanto, en consonancia con la valoración de la insubordinación productiva de los situacionistas, Jorn perturba las jerarquías de significación al interior de sus pinturas modificadas; usa (mal) ciertos elementos, ya sea frustrando su presunta significación dentro de un sistema semiótico particular, ya sea enfatizando su potencial para generar significados dentro de otros regímenes distintos. Es decir, las intervenciones de Jorn reorientan ciertas imágenes (cuerda, ave, mano, etc.), convertirtiéndolas, de ese modo, en elementos de un código lingüístico que trabaja independientemente, o incluso en contra, de su uso visual ostensible como imágenes representadas. De manera similar, una parte de la fuerza de las fuentes apropiadas por Jorn reside en que su representabilidad provee un trasfondo contra el cual sus abstracciones tienen la capacidad de significar, como marcas oposicionalmente opacas e insubordinadas, que no pueden ser asimiladas a un discurso referencial. (Es decir, si la fuente de Jorn fuese uno de los cuadros chorreados de Pollock o una de las composiciones suprematistas de Malevich, la fuerza de sus propias marcaciones sería bastante diferente). Vale la pena enfatizar este punto: la mera disrupción de la superficie ilusionista de sus fuentes, simplemente restituiría una autoridad en lugar de otra, y la calidad distintivamente détournée de las intervenciones de Jorn deriva del modo en el cual impide a cualquier marco hacerse dueño de una autoridad segura. Este sentido situacionista del «diálogo » emerge no sólo de la implicación de elementos particulares en múltiples sistemas de significación, sino también del método de Jorn de, conspirativamente, inscribirse a sí mismo y a sus propios gestos insurreccionales incluso en el espacio de la más complaciente pintura original. Como hemos visto, tanto con la mise en abîme de los grafiti en L'avant-garde se rend pas como con el anuncio de una destreza manca en Les deux pingouins, Jorn traza analogías entre sus propias actividades y las de sus sujetos, enredando irresolublemente, por tanto, la relación entre proceso y producto, de modo tal que ni pintura ni (sobre)pintada pueden asegurarse una prioridad inequívoca o una autoridad incontestable sobre la otra. Pues incluso cuando el retrato original amenaza con desaparecer bajo las salpicaduras y chorreaduras de las modificaciones de Jorn en el segundo panel de Les deux pingouins, el juego del título de Jorn ayuda a sostener el diálogo que el détournement situacionista requiere. Al mostrar su mano, por así decirlo, Jorn invita al espectador a reconocer los juegos de palabras, pero toda la fuerza del sentido de dichos juegos de palabra requiere que el espectador reconozca simultáneamente ambos niveles de la pintura desviée, sin permitir que una predomine sobre la otra o colapse por completo en ella.

En una buena cantidad de otros détournements, Jorn también insiste en hacer visible aquello que es borrado, a la vez que muestra la sobrepintura oscurecente. En varias obras, Jorn capta la imagen de patos y los enfatiza; entre las modificaciones de 1959, por ejemplo, se encuentran Le lac de canards y el desopilantemente ridículo Le canard inquiétant - Como con los pingüinos, esta materia aviaria no es casual. El francés canard, como el inglés « duck» [y a diferencia del español «pato »], denota no sólo el ave acuática, sino también el lienzo de algodón de la pintura misma -que el realismo trata de volver invisible y que Jorn vuelve a poner a la vista-. Al mismo tiempo, el óleo húmedo y líquido con el cual oscureció más el pato de los lienzos originales, como lo demuestran sus chorreaduras y corridas, bien podría haber evocado el sentido adjetival de canard -très mouillé [muy mojado]- y frases idiomáticas como muillé y trempé comme un canard. Resulta que los grafitis pictográficos de L'avant-garde se rend pas están lejos de ser gratuitos: un 
ave y un hombre manco -canard et manchot- en diálogo con los otros détournements de Jorn, una vez más dejan su huella conversacional en la superficie de la pintura.

\title{
Un mensaje en una botella
}

\author{
La vida es una anarquía de claroscuros. \\ Georg Lukács \\ La perfección del suicidio está en la ambigüedad. \\ Guy Debord
}

En 1957, justo cuando se estaba fusionando la Situationniste Internationale, Jorn y Debord colaboraron con el litógrafo e impresor V. O. Permild para hacer dos libros extraordinarios, Fin de Copenhague y Mémoires ${ }^{50}$. Hasta cierto punto, estas obras traen a la memoria el récit détourné [relato desviado] de Gil Wolman «J'écris propre », el cual había sido publicado el año anterior en la revista protosituacionista Les lèvres nues. Como la historia de Wolman, estos libros se anuncian como obras collage "entièrement composées d'éléments préfabriqués» [enteramente compuestas de elementos prefabricados]; pero a ese lenguaje recuperado de la basura, fragmentado, y suturado, le agregan ilustraciones lineales, fotografías, y las distintivas sobrepinturas con chorreaduras, salpicaduras y corridas de Jorn. En el caso de Mémoires, el cual se divide, precisamente, en dos secciones fechadas, los elementos del collage fueron rescatados de una variedad de libros, revistas populares, y souvenirs de los días letristas de Debord, los cuales son evocados con la implacable «melancolía de un mundo en disolución » ${ }^{51}$. En el caso de Fin de Copenhague, el cual es a la vez más ácido y gracioso en su crítica de la cultura espectacular, todo el material fue supuestamente pirateado de un solo kiosco de revistas y montado en un solo día inspirado ${ }^{52}$. Pese a toda la prisa de la improvisación, sin embargo, el ingenioso humor y la economía de recursos del texto son soberbios; si el anuncio de una película parece hacer referencia a la société du spectacle, por ejemplo, su colocación está motivada tanto porque el título -Vera Cruz- rima con el barco de crucero que aparece en la misma página, como porque además «superscope » repite gráficamente el « $\underline{\text { Cope }}$ nhague » escrito super, o sobre este.

Construido como détournements de material encontrado, reorganizado para contar nuevas historias, el lenguaje de estos libros también es sometido a su propio détournement análogo. Calembures específicos, como vimos, sirven efectivamente para mantener el diálogo de las modificaciones de Jorn, pero la paronomasia, como tal, asímismo forma parte integral de la práctica situacionista. Al nivel de la palabra, el juego de palabras mismo es un détournement. Los juegos de palabras se distinguen de la polisemia o la mera homofonía al mantener dos registros simultáneamente en juego y en diálogo el uno con el otro, en lugar de simplemente alternar entre ellos. En un juego de palabras, los conjuntos grafémicos o fonémicos de una palabra son secuestrados, de modo que la dirección aparente de la referencia -el telos semántico de la palabra- es desviado de su destino ostensible. Sin embargo, ese significado no es simplemente evitado; una huella de su vector semántico siempre permanece, en tanto la palabra gesticula al mismo tiempo hacia el sentido original y el modificado. En resumen, un juego de palabras es la memoria eidética tomando por asalto a la palabra. En sus libros collage, Jorn y Debord trabajan para crear registros contextuales en campos semánticos tan precisos que el llamado de la referencia obliga a las palabras a flotar en resonancia suspendida entre las fuerzas en competencia en un juego equilibrado. 0 quizás el efecto de esas palabras es menos como un champ magnétique y más como los movimientos indecidibles de partículas subatómicas, 
que en simultáneo están virando hacia distintos e irreconciliables estados de las cosas, trazando sus caminos clinanimáticos [clinanimatics] entre la materia subatómica bajo la influencia de la semántica gravitatoria.

Algunos ejemplos de estos juegos de palabras, y del grado en el cual Jorn y Debord mantienen cuidadosamente el equilibrio entre sus referencias simultáneas sin privilegiar una sobre la otra, irán emergiendo a lo largo de este capítulo. Para empezar, quiero concentrarme en el modo en que Fin de Copenhague enfatiza su estatus de libro al jugar con los elementos de su estructura formal como si fueran palabras. Encuadernado originalmente en pasta, la cubierta, hecha con lo que parecería ser un periódico danés, luce un anuncio a gran tamaño de productos para afeitarse. Domina la tapa un titular que dice « ¡barberspejlet! » [espejo de afeitar], y la contratapa es ocupada por la imagen de un hombre mirándose al espejo mientras se afeita. Por ende, la cara pronunciadamente blanquecina de ese afeitador, tanto literal como figurativamente, a une mine de papier mâchés3. Más aún, estar aburrido y estar afeitado es lo mismo en francés (être rasé), una coincidencia que Jorn y Debord explotan para conectar la cubierta del libro con sus líneas iniciales: "Copenhague(:) je passais mon temps (...) (avec) la sensation d'être écrasé de fatigue [pasaba el tiempo (...) (con) la sensación de estar aplastado de cansancio]». Para resaltar aún más la conexión, ese « écrasé » [aplastado] un poco melodramático inscribe literalmente "rasé » [afeitado]. Las hojas de afeitar son, en todo caso, centrales para el armado de las páginas collage del libro; en Copenhague, se hace referencia a las banalidades y los aburrimientos de Copenhague a través de los shavings (copeaux) $)^{54}$ de los collagistas. Sumando la copia del anuncio, estas referencias deslizantes se acumulan a un ritmo que marea, la línea de la publicidad que aparece en la parte de abajo de la tapa abre con «år » [año], sugiriendo la cicatriz (danés ar) del corte de una afeitada, que podría haber sido causada por el producto publicitado como la «skarpeste klinge » [más afilada afeitadora] o «blad» [hoja] -un homónimo danés que hace caer perfectamente juntos el filo de la navaja y el « periódico » (blad) que fue cortado para armar ese mismo libro que lo contiene. Esta autorreflexividad es subrayada por la autorreflexión de la imagen de contratapa -un hombre mirándose a sí mismo en el barberspejlet- y, en una línea borrada de modo que uno deba, de hecho, mirar a través de ella, la leyenda al pie del afeitador invita a "gennem» [mirar a través]. Siguiendo este ejemplo, y mirando en sentido figurado directamente a través del libro desde esa línea hasta la posición paralela en la tapa, el lector encuentra un juego interidiomático de palabras con « videre »: adjetivo en danés que significa "más amplio " o "más ancho ", y en latín es el infinitivo del verbo «ver ». En Fin de Copenhague, más allá de la obvia burla de la cultura espectacular, estas referencias anafóricas y catafóricas más sutiles invitan al lector a afilar la percepción, mirar y escuchar con cuidado.

Además, este tipo de autorreflexividad bibliográfica inscribe a los autores del libro en el mismo tejido del material de su obra, repitiendo el modo en el cual vimos que Jorn se involucra a sí mismo en las redes significantes de sus pinturas. Fin de Copenhague fue publicado como édition de luxe limitada a 200 ejemplares: « Ein wertvolles Buch » [un libro valioso], como proclama una de sus propias páginas usando letras góticas en negrita. En concordancia con el uso prevalente en el mundo del arte, Jorn firmó a mano cada ejemplar, pero el libro es ingeniosamente refrendado por su mismo armado y diseño. El arte de la encuadernación es, [en inglés (binding) y en francés (reliure)] por supuesto, el arte de juntar firmas, y la « firma » del tercer colaborador, por ejemplo, no sólo aparece en el colofón, sino también en una mise en abîme con un pedacito de papelería comercial 
de su imprenta: «Permild \& Rosengreen », pegado bajo el anuncio de una película. De manera similar, con un desplazamiento (сдвит) que atraviesa los límites entre palabras, el nombre de Debord surge explícitamente de la copia de un anuncio para un «store kol de bord " [crema untable grande]. Las otras inscripciones, sin embargo, son menos obvias. Para empezar (d'abord), en esta obra hecha de recortes (des bordes), la impresión está corrida: la mayoría de las imágenes pegadas en el collage se proyectan más allá de sus límites, y todos los motivos pintados y superpuestos sobrepasan los bordes y se salen de la página, es decir, el diseño gráfico continuamente déborde (desborda) los márgenes. Adicionalmente, esos flujos de tinta colorean los alrededores y las áreas circundantes ( abords) de los planos de la ciudad, pegados o esquematizados, que llenan varias páginas, así como el acercamiento (abord) al "Mt Kilimanjaro" en otras. El nombre de Jorn también aparece implícitamente a lo largo del libro; en tanto obra hecha de periódicos ( journaux) que documentan el trabajo de una sola jornada (journée), Fin deviene una página en el diario de abordo (journal de bord) colectivo de Jorn y Debord -referencia náutica reafirmada por las tablas meteorológicas, mapas marinos, y publicidades de cruceros que contiene-.

De hecho, dado este contexto náutico, las derivas semánticas del lenguaje apropiado en Fin de Copenhague sugieren -o derivan de- un concepto central situacionista: la dérive (deriva, desviación, descarrilamiento) ${ }^{55}$. En tanto terme de métier situacionista, « dérive » denota « une technique du passage hâtif à travers des ambiances variées » [una técnica de paso apresurado a través de ambientes diversos $]^{56}$. $O$, en otras palabras, un deambular desorientado, usualmente por calles citadinas y edificios abandonados. Creado por Chtcheglov, Rumney, y otros "nuevos urbanistas ", ese deambular lúdico e inmotivado - «éambulation » [andar sin rumbo] en contraste explícito con « promenade » [paseo]es llevado a cabo sin tener en cuenta el hábito o las coerciones del planeamiento urbano, y sin ningún otro objetivo más que sintonizar con la atracción o repulsión del paisaje y rendirse a sus posibilidades ${ }^{57}$. La dérive, por lo tanto, mapea microclimas de «espacio psicogeográfico » en concordancia con una ecología de la emoción, en vez de con una arquitectura o una distancia física establecidas:

Une ou plusieurs personnes se livrant à la dérive renoncent, pour une durée plus ou moins longue, aux raisons de se déplacer et d'agir qu'elles se connaissent généralement, aux relations, aux travaux et aux loisirs qui leur sont propres, pour se laisser aller aux sollicitations du terrain et des rencontres qui y correspondent. Una o varias personas que se abandonan a la deriva renuncian, durante un tiempo más o menos largo, a los motivos para desplazarse o actuar que acostumbran generalmente, a las relaciones, a los trabajos y a los entretenimientos que les son propios, para dejarse llevar por las solicitaciones del terreno y los encuentros que a él corresponden. ${ }^{58}$

En pocas palabras, el dérèglement de Rimbaud aplicado al viaje urbano. Así, los situacionistas se suman a la multitud de todos aquellos otros promèneurs, flâneurs, y vagabundos por ciudades irreales: De Quincey, de Nerval (Labrunie), Baudelaire, Whitman, y -de gran importancia- Aragon y sus camaradas surrealistas. Contra la tradición del faire aller, sin embargo, les dériveurs no esperan pasivamente la emoción lasciva de un choc a la vuelta de la esquina, ni atisbar, como voyers, une scène chatouillement, ni siquiera esperan necesariamente explorar nuevos e ignotos territorios; ellos están dispuestos a crear activamente las situaciones de su vagabundeo. En efecto, sin estar lo suficientemente perdidos o bebidos como para lograr la desorientación apropiada de un flujo no aerodinámico, siempre pueden valerse de las tecnologías del dérivant, como usar el mapa de una ciudad mientras están en otra ${ }^{59}$. 
La dispersión y el movimiento de la pintura que fluye a través (y fuera) de las páginas de los libros situacionistas de Jorn y Debord remeda obviamente la dérive. En consencuencia, Greil Marcus lee las pinturas de Jorn en Mémoirs de forma representacional: las « líneas de color aparentemente ciegas se convierten en avenidas, entonces las palabras y las fotos de Debord transforman en laberintos las avenidas de Jorn $»^{60}$. Hasta cierto punto, y para algunas páginas, esto es ciertamente así, pero como lo manifiesta Fin de Copenhague, la pintura aparentemente abstracta de Jorn también es figurativa en otro sentido; las distintas capas líquidas de estos libros también señalan otros referentes. En efecto, la familiaridad del aspecto de estos diseños no proviene tanto de los lienzos de Jorn -aunque también se los puede ver ahí- sino de las escenas autobiográficas de los filmes de Debord. Atisbados en fotogramas de Sur le passage de quelques personnes... (1959) o Critique de la separation (1961), son de hecho la puesta en escena misma del artístico y revolucionario mundo bohemio habitado por Debord y Jorn. Con chorreaduras, salpicaduras, embadurnamientos y marcas de dedos, Jorn mancha las páginas de sus libros como si fuesen mesas de café dispuestas entre rayones y escombros en los lugares favoritos situacionistas como Chez Charot, Café de Mabillon, Chez Moineau, o en alguno de los otros bares sórdidos de Saint-Germain-des-Prés, en donde Gil Wolman recuerda haber vomitado " copiosamente ${ }^{61}$. Más aún, en donde clientes amontonados, descuidados y embriagados, -tratando de sortear las mesas poco sólidas dispuestas muy cerca las unas de las otras- arrojaban platillos con charquitos líquidos sobre las mesas enclenques, dejando que se derramaran y formasen charcos caprichosamente, en donde manos temblorosas por haber dormido demasiado poco o tomado demasiados tragos, calculaban mal o gesticulaban de modo exageradamente enfático, y en donde, más tarde, dibujaban perezosamente en lo derramado y salpicado con fósforos quemados, haciendo trazados en las cenizas de cigarrillo que a su vez todo lo moteaba.

31 No es mi intención aquí ser gratuitamente discursivo; lejos de ser casuales, los detalles mismos de la vida cotidiana « en la terraza del café » ocupan un lugar central entre los relatos inscritos en los libros situacionistas y entretejidos entre sus fragmentos ${ }^{62}$. Con sus recuerdos teñidos de vino, las páginas de los libros de Jorn y Debord registran un mundo perdido de hábitos, gestos y etiqueta: en suma, el sentido de БУТ о vie quotidienne que es tan central para la teoría situacionista. En otras palabras, realizando el sueño con el cual Chtcheglov había ayudado a lanzar la IS, Jorn y Debord estaban construyendo la hacienda «donde el vino es acabado con fábulas de un viejo almanaque». O, como bien puede haberlo repetido el estilo situacionista, donde los viejos almanaques acaban en vino. En efecto, la edición contemporánea de la revista Internationale situationniste $\left(\mathrm{n}^{\circ} 3\right)$ propone una novela tridimensional, cortada en fragmentos pegados en botellas de ron, dejando que el lector siga el relato a su antojo; Mémoires y Fin de Copenhague invierten esencialmente este esquema, imprimiendo riachuelos de ron en las páginas de una novela fragmentada.

La creación de textos situacionistas, aunque no la creación de las situaciones mismas, se dio precisamente bajo tales circunstancias -y bajo la influencia del alcohol-. Al rememorar el espacio y la historia de su propia construcción, estos libros cumplen con un requisito clave de la estética situacionista: « la principale force d'un détournement étant fonction directe de sa reconnaissance, consciente ou trouble, par la mémoire » [siendo la fuerza principal de un desvío función directa de su reconocimiento consciente o borroso, por la memoria] $]^{63}$. Como apunta Debord en el prólogo a la reimpresión de Mémoires de 1993, el libro "était en grande harmonie avec la vie réelle que nous menions alors » 
[estaba en gran armonía con la vida real que nosotros llevábamos en aquel entonces]. Y esa vida se consumía en el alcohol. La IS fue fundada « en un estado de semi ebriedad », y el sondeo de las fotografías que documentan las reuniones y congresos de CoBrA, los letristas, y la IS revela una constante entre las cambiantes localidades y personalidades: las ubicuas botellas de alcohol, copas de vino, y manchas de cerveza ${ }^{64}$. En particular, el alcoholismo propio de Debord es bien conocido: «c'est un fait», escribe, "que j'ai été continuellement ivre tout au long du periodes de plusieurs mois; et encore, le reste du temps, avais-je beaucoup bu » [es un hecho que estuve continuamente borracho durante períodos de varios meses; y es más, el resto del tiempo bebía mucho] ${ }^{65}$. Debord dedica todo el tercer capítulo de su autobiografía Panegyrique -una obra de una melancolía arrolladora, sólo interrumpida por su megalomanía- al alcohol, del cual afirma que « a été la plus constante et la plus présente » [fue (la cosa) más constante y más presente] en su $v^{v i d a}{ }^{66}$. En particular, escribir y beber se topan con fuerza en el relato de Debord: «J'ai écrit beaucoup moins que la plupart des gens qui écrivent; mais j'ai bu beaucoup plus que la plupart des gens qui boivent " [he escrito mucho menos que la mayoría de la gente que escribe; pero he bebido mucho más que la mayoría de la gente que bebe ${ }^{67}$. Cuando, con toda la amargura de los deshechados, a Michèle Bernstein se le ocurre que las purgas de Debord se extendían a aquellos que depositaban «sus copas de vino en la mesa de un modo aburguesado", su figura sarcástica no es casual. Fin de Copenhague y Mémoires registran las marcas dejadas por esas copas de un modo diferente ${ }^{68}$.

En efecto, no dejemos que el punto pase desapercibido, Fin de Copenhague hace gráficamente explícita la ecuación del alcohol derramado con la pintura vertida por Jorn. Además de la etiqueta de scotch que flota en el margen superior de una página (janticipando por seis años el «arte scotch» de Gil Wolman!), el libro incluye varias ilustraciones de botellas inclinadas, ya sea insertadas en un ángulo horizontal y amenazando con volcarse, ya sea vaciándose de una vez sobre la página. Incluso si, por el contrario, « les bouteilles se couchent » [las botellas se acuestan] en Mémoires, reaparecen una década después, cuando pueden ser avistadas en reserva detrás de las barricadas en el verano de 1968: vaciadas, bebidas hasta la última gota, détournées, vueltas a llenar con gasolina y selladas con trapos para hacer cocteles molotov. Los libros de Jorn y Debord abogan por esa revolución, y la intoxicación situacionista está íntimamente ligada a su revolución de la vida cotidiana, aunque, quizás, ellos no previeron el modo en el cual el consumo de alcohol se convertiría en un prerrequisito necesario para la acción revolucionaria: las herramientas del alcohólico y del bricoleur que pelea en las calles, vinculadas unas con otras en proporción directa. Sin embargo, cuando hicieron encuadernar Mémoires en papel de lija grueso, deben haber previsto la alusión implícita. Ostensiblemente, esta encuadernación estaba pensada para destruir con cada uso los libros adyacentes a Mémoires en el estante, socavando de este modo su utilidad en forma agresiva con un potlatch de códices; pero, al estar encuadernado en papiers de verre (literalmente "papeles de vidrio »), el libro no sólo evoca spectacles, y hace una alusión ingeniosa al espejo de afeitar de la cubierta de Fin de Copenhague (incorporando incluso una réplica táctil de la barba aún sin afeitar del hombre afeitándose), sino que también se convierte en un receptáculo adecuado para los líquidos -sean alcohólicos o incendiariosque contiene ${ }^{69}$.

Como emblema de ambas, de la revuelta en contra del Estado y de la revolución de la vida cotidiana, lo espirituoso, en los libros situacionistas, está siempre imbuido en política. Dado que ninguno de los comentaristas de los libros situacionistas siquiera menciona la 
prevalencia temática de este tópico, quiero concluir está sección dejando en claro cuán plenamente el aroma de ese alcohol politizado se expande a través de Mémoires y Fin de Copenhague, los cuales -inclusó más allá de la pintura de Jorn y las figuras visuales de botellas- están empapados en alcohol. En efecto, con lo que bien puede ser «todos los placeres del verano " o, al menos, "todas las condiciones necesarias", ya la primera página de Fin de Copenhague cuenta con una carta danesa de bebidas impresa en negrita:

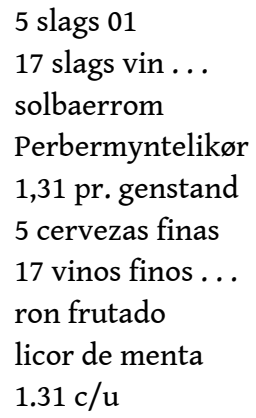

Después de este aperitivo, el « Drink-£300 » subrayado resalta de manera similar en el centro de otra página más adelante y, en otra apertura de página, la copia bilingüe de una publicidad de Dubonnet, que le pone glamour al espíritu de la « disipación », es reflejo de la afirmación de la parte superior de la otra página: « Dix minutes après, l' émotion étant / dissipée, on buvait le champagne» [diez minutos después, la emoción habiéndose / disipado, bebíamos champaña]. Las referencias de ese tipo son todavía más comunes en Mémoires, en donde la primera página anuncia metatextualmente: «il s'agit d'un sujet profondément imprégné d'alcool» [se trata de un tema profundamente impregnado en alcohol]. El collage de fragmentos que sigue a continuación corrobora esta afirmación inicial. En una página Debord declara, más bien pomposamente: «el vino de la vida ha sido decantado, y tan solo quedan los residuos de esa pomposa bodega ». Luego, algunas páginas más adelante, vira de lo metafórico a lo literal, al admitir que, de hecho, «il reste du vin » [todavía queda vino]. « Nous bûmes», rememora Debord, "outre mesure de toutes sortes de vins » [bebimos toda suerte de vinos más allá de cualquier medida], y entre «tous les sirops somnifères du monde » [todos los jarabes somníferos del mundo], pregunta: « Moi, ivre? » [iYo, borracho?]. Debord registra haber estado « sous l'influence de l'alcool» [bajo la influencia del alcohol] o "pas ivre en ce moment» [no (estar) borracho en ese momento], y diferencia, como un conocedor de la intoxicación, entre «boire » [beber], « en train de boire » [estar bebiendo], y «Après boire » [después de beber $]^{70}$.

El hecho de que estos libros estén bañados en alcohol también hace tambalear otras citas. Una parte del material incluido en los collages de Mémoires, por ejemplo, los dibujos de una historia vagamente porno, pero, en su nuevo contexto intoxicado, lo alcohólico y lo orgásmico se confunden para encajar bellamente -«Beau comme le tremblement des mains dans l'alcoolisme» [bello como el temblor de manos del alcoholismo], como escribiría Lautréamont en una línea apropiada por Debord ${ }^{71}$.

Puis les secousses s'espacent, s'atténuent, s'apaisent (...). Elle se mit àtrembler, sans répondre (...). Ainsi les grandes convulsions pas encoreentierèment apaisées (...). A un moment, si je ne l'avais retenue, elle seserait affalée sur le sol en proie à des convulsions

Luego las sacudidas se espacian, se atenuan, se calman (...). Ella se puso a temblar, sin responder (...). Así, las grandes convulsiones aún no del todo calmadas (...). En un momento, si yo no la hubiera sostenido, se habría derrumbado en el suelo presa de sus convulsiones. 
De manera similar, el alcohol tiñe otros elementos aparentemente fortuitos de esos collages. Las recurrentes referencias piratas a Robert Louis Stevenson son motivadas no sólo porque representan el espíritu de un estilo de vida anti-mercado, criminal y anárquico, sino también porque son hechas bebiendo (« La boisson (...) [les a] expédié »), y cantando "Yo-ho-ho! et une bouteille de rhum » [jYo-ho-ho y una botella de ron!] hasta el final -una línea que resuena a lo largo de Mémoires siendo utilizada como estribillo del libro de Debord al igual que de la canción de Cochon-Rôti-. La descripción "se dessèche » [se deseca] se vuelve igualmente cargada en Fin de Copenhague, en donde los recurrentes mapas del tiempo revelan una lógica alcohólica: predicen cuán húmedos o secos serán los días y semanas por venir, juntando corrientes frías y corrientes de alcohol ${ }^{72}$. Si la colaboración entre Jorn y Debord fue espontánea, y por tanto carece de "drafts " [bocetos] en el sentido artístico, sin embargo, debe haber atravesado una serie de pruebas (épreuve si no teneur) y, en efecto, incluso los símbolos de los grados en las repetidas cartas meteorológicas empiezan a verse como indicaciones de pruebas de graduación alcohólica más que de temperatura. Todo lo cual converge, de manera significativa, en el juego de homofonía entre el inglés « fan » y el francés « fin » en la página de Dubonnet -una deriva lingüística bellamente complejizada cuando la marea le da la espalda a la fonética: un alerón "fin» [estabilizador] en francés es, significativamente, une dérive, (y uno no debería olvidar la imagen de un avión con su " tail fin » [alerón de cola] silueteado en Fin). Al final, la diferencia fonética entre la fin de Copenhague y le vin de Copenhague (vino de Copenhague) o la diferencia gráfica entre el título real y Fine de Copenhague (aguardiente fino de Copenhague) es provocadoramente mínima ${ }^{73}$. Cuestión de conocedores.

\title{
Tiempo perdido
}

\author{
Le meilleur, c'est un sommeil bien ivre, sur la grève. \\ Arthur Rimbaud \\ La vida nunca puede desorientar demasiado. \\ Guy Debord
}

Hemos visto que el alcohol no es simplemente un accesorio biográfico, ni tampoco una mera casualidad de la puesta en escena de los lugares favoritos de los situacionistas. Asociado como está a la transformación política de la vida cotidiana, y trabajando en pro de un détournement agudizado del lenguaje de los juegos de palabras en los libros situacionistas, el alcohol también está intimamente ligado a otro tema central de los libros de Jorn y Debord, y a uno de los objetos centrales de la crítica de Debord: el tiempo. El alcohol puede alterar fundamentalmente la relación que uno tiene con el tiempo. En un sentido banal, puede obviamente organizar el tiempo, como en la « hora del aperitivo »o a través de la asociación de tragos específicos con momentos específicos del día, pero los efectos también pueden ser más profundos ${ }^{74}$. Quiero dejar en claro que con esto no me refiero a la entrada en calor del primer trago (la cual por supuesto puede revivirlo a uno y entusiasmarlo sobre el futuro), ni tampoco pretendo hacer referencia a la insignificante ebriedad de los primeros pocos (la verborrea de los borrachos llorones, que traen el pasado al presente como si fueran cajas sacadas de la bodega para ser evocadas); me refiero a una verdadera, completa, y profusamente oscura intoxicación. Una intoxicación de tal magnitud que produce una especie de presente continuo: no como el de Stein, que empieza una y otra vez, sino una intoxicación que expande y suspende el presente. Y de ese modo lo oblitera. En pocas palabras, el efecto conmocionante de levantar la vista de la copa y ver el reloj. Hablamos de « olvidar todo sobre el tiempo », pero el shock es que lo 
hemos olvidado todo sobre el tiempo mismo. 0 , más bien, que hemos reconocido una nueva experiencia del tiempo desanclada de su regulación por medio de ese reloj: un tiempo a tal punto en estupor que se olvida de sí mismo en una ceguera etílica ${ }^{75}$. Ese punto «est au delà de la violente ivresse, quand on a franchi ce stade: une paix magnifique et terrible, le vrai goût du passage du temps » [está más allá de la borrachera violenta, cuando se ha franqueado ese estado: una paz magnífica y terrible, el verdadero sabor del pasaje del tiempo] ${ }^{76}$.

Este efecto de un tiempo reorganizado por el alcohol, hay que advertirlo, es bastante diferente de la elaboración de Gilles Deleuze sobre la reorganización del tiempo por el alcoholismo ${ }^{77}$. En sus términos: «El alcoholismo no se presenta como la búsqueda de un placer, sino de un efecto. Este efecto consiste principalmente en lo siguiente: un extraordinario endurecimiento del presente $»^{78}$. De hecho, en Panegyrique Debord ejemplifica precisamente ese tiempo alcohólico, con su frecuente uso de «j'ai bu». «El alcohólico », argumenta Deleuze, « no vive nada en el imperfecto o en el futuro, sólo tiene pretérito perfecto [passé composé] (...) como si la dulzura del participio pasado viniera a combinarse con la dureza del auxiliar presente ${ }^{79}$. Sin embargo, endurecer el presente en lugar de obliterarlo, iría en contra de los sueños situacionistas; un presente congelado e introducido en el futuro como un artefacto -un espectáculo exhibido en el museo del tiempo- fracasaría en el intento de constituir una «situación» en términos de Debord. «Las situaciones son concebidas como lo opuesto a las obras de arte, son intentos de preservación y valorización absoluta del momento presente $»^{80}$. Aunque Deleuze reconoce que también existe el tiempo de la necesidad alcohólica, en el cual « todo futuro es vivido como futuro-perfecto " [futur-antérieur], su discusión sobre Lowry, sorprendentemente, pasa por alto el tiempo intoxicado del alcohol mismo: el tiempo "circunfluyente » y "paralizado» descrito en las páginas finales de Under the Volcano ${ }^{81}$. Con la pátina nostálgica apropiada para el tono de Debord en Panegyrique, Deleuze proclama: «el alcohol es a la vez el amor y la pérdida de amor. (...) el objeto, la pérdida del objeto y la ley de esta pérdida $»^{82}$. Uno no puede evitar oír el ejemplo que se abstiene de dar: el tiempo y la pérdida del tiempo. En esa pérdida del tiempo es que se encuentran las situaciones.

Pese a toda su experimentación y su radicalidad, las colaboraciones de Jorn y Debord no logran expandir su comprensión del tiempo revolucionario al nivel del libro mismo. Debord, de forma bastante predecible, critica las narraciones lineales y secuenciales; « una cronología de eventos » semejante evoca « un movimiento inexorable que aplastó a las personas que tenía delante $»^{83}$. Mémoires, no obstante, pone en marcha precisamente cronologías semejantes al fechar de manera cerrada y secuencial el material, en perfecta correspondencia con su secuencia estandar, lineal y codexical (el lomo a la izquierda y las páginas dadas vuelta una tras otra de derecha a izquierda). En contraste, las páginas discontinuas y fragmentadas de Fin de Copenhague trabajan contra la linealidad hasta tal punto que su parataxis impide una transición fluida de una página a la siguiente. En efecto, la estructura de Fin se puede leer como un modelo de soviets anarquistas: una federación que resiste a la subordinación de la página individual, tanto a un designo mayor como a una autonomía irrelevante. Así, las páginas de Fin niegan la prioridad pero comparten motivos recurrentes, creando de este modo una analogía espacial al « tiempo individual y colectivamente irreversible, cuyo carácter es lúdico y el cual incluye, presente en él de manera simultánea, una variedad de tiempos autónomos, pero efectivamente confederados $»^{84}$. Al final, sin embargo, la forma convencional de entender la página como « una suerte de espacio cerrado » que se sucede el uno al otro en una 
ordenada « sucesión de momentos artificialmente distintos », como una « acumulación de intervalos equivalentes» o de ejemplos espacializados de «tiempo cortado en iguales fragmentos abstractos", está demasiado grabada para ser compensada por una exacerbación de su cerramiento discreto del espacio ${ }^{85}$. Incluso en Fin de Copenhague, el formato de las páginas en definitiva pone a funcionar las mismas estructuras que Debord critica.

Esta puede parecer una evaluación más bien mezquina y dura de la obra de Jorn y Debord, a la cual sólo se llega interrogando los aspectos más triviales e incidentales de un libro que, de otro modo y como acabo de argumentar hasta cierto punto, hace gala de una práctica situacionista ejemplar. Pero la relevancia de tales detalles, y la constante atención que requieren, es precisamente la lección que el formalismo radical puede aprender de la práctica situacionista. El sueño de la política requiere ambas cosas: una guardia sin descanso, una vigilancia insomne con los ojos sin párpados de Argos, pero también -como anunciaba el título del manifiesto de Michèle Bernstein en el primer número de la IS- decir «Pas d'indulgence inutile» [Nada de indulgencia inútil]. Despertamos al amanecer del sueño de la política con precisión, y « oui, l'heure nouvelle est au moins très-sévère » [sí, la nueva hora es al menos muy severa] ${ }^{86}$.

\section{NOTES}

1. Gilles Deleuze y Félix Guattari, Capitalisme et schizophrénie, París: Minuit, 1972/1980. Trad. ing. B. Massumi. Mineápolis: University of Minessota Press, 1987, p. 213. [Mil mesetas. Capitalismo y esquizofrenia. Trad. J. Vázquez Pérez con la colaboración de U. Larraceleta, Valencia: Pre-Textos, 2000, p. 218.]

2. Gilles Deleuze y Félix Guattari, op. cit., p. 222 [p. 225].

3. Bruce Andrews ofrece una crítica más exhaustiva cuando sugiere que ese tipo de lecturas no sólo fallan el tiro, sino que además consolidan el status quo: "Cuando todo es enmarcado en términos de su eficacia, la obra que es promovida como eficaz es una obra que, para mí, simplemente refuerza las mismas cegueras que creo son centrales al modo en que el sistema se mantiene unido ». Paradise and Method: Poetics and Praxis, Evanston: Northwestern University Press, 1996, p. 63-64. [Para todas las referencias y citas que no incluyan información sobre las correspondientes versiones publicadas en castellano, la traducción me pertenece.] Más abajo elaboro la naturaleza de esas cegueras.

4. Jed Rasula, "The Politics of, the Politics in ", in : Robert von Hallbert (ed.), Politics and Poetic Value, Chicago: University of Chicago Press, 1987, p. 317.

5. [Se refiere al cuarto capítulo del mismo libro en el cual fue publicado el presente texto: p. 71-87 .]

6. Bruce Andrews, Paradise, op. cit., p. 50. En respuesta a la pregunta de Marjorie Perloff -que bien podría hacérsele aquí a mi propio proyecto- «Si al lenguaje se le niega (...) su 'transparencia', ¿cómo será llevado a cabo el 'diálogo social'? », Andrews contestó: « Entonces, 'diálogo social' no sugiere una respuesta directa o sin mediaciones a los referentes sociales (la cual en demasiadas ocasiones y en su forma 'llana' o 'literal' da por sentado el aparato referencial). En cambio, propone un diálogo con lo social, con un todo menor que la totalidad positiva, y con el modo en 
que este es producido y negociado, con sus principios (cambiantes) de orden y organización ». Op. cit., p. 81.

7. Bruce Andrews, op. cit., p. 51.

8. Arthur Rimbaud, Une saison en enfer/Les illuminations, Londres: Oxford University Press, 1973, p. 62, 13. [Una temporada en el infierno. Trad. O. Girondo y E. Molina. Buenos Aires: Edicom, 1970, p. 39, disponible en < http://www.relpe.org/recursos/libros/UnatemporadaenelinfiernoRimbaud.pdf>, página consultada el 1/12/2017].

9. Para un panorama del clima político de la izquierda francesa en esa época, véase Gombin, Richard. «French leftism ». Journal of Contemporary History 7, 1972, p. 27-50. Para un movimiento relacionado, aunque muy diferente, fuera de Francia, considérese el grupo holandés Provo. En el capítulo 4, discutiré la influencia de Georges Bataille sobre teóricos posteriores; simple y francamente, su significación no puede ser subestimada.

10. Pese a que ellos lo negaran, la influencia patafísica en los situacionistas es clara, tal y como lo atestigüan líneas como estas: « Il n'y a pas problèmes il n'y a que des solutions ». Les lèvres nues n 4, enero de 1995.

11. El hermano de Jorn, Nash, más tarde rompería con la IS para fundar la «Bauhaus situacionista ", cuyo centro sería Drakagygget, donde publicaría una revista epónima; el grupo alcanzó su mayor fama cuando proclamaron haber decapitado la estatua de la sirenita en el puerto de Copenhague. (Tan sólo queda fantasear sobre qué revisiones le habría hecho la Bauhaus situacionista a la reciente película de Disney, La sirenita). Debord se molestó tanto por la defección que acuñó el término Nashistouse, glosándolo meramente como «vulgar ». Con una ferocidad cristalina, Debord eleva el insulto a categoría de género literario, lanzando imprecaciones de un modo tan brillante que, en comparación, hace pasar vergüenza a las escuetas vulgaridades de BLAST.

Para una introducción sobre los letristas, véase Stephen Foster (ed.), Letrism: Into the Present, Edición especial de Visible Language 17, $\mathrm{n}^{\circ} 3$.

12. El papel exacto de la IS aquel verano en las calles de París está en disputa, sin embargo, la articulación de conceptos anarquistas por parte de los situacionistas jugó, como mínimo, un rol innegable en el transcurso de los acontecimientos. En 1963, Debord profetizaba: «nous n'organisons que le détonateur " [nosotros no organizamos más que el detonador] (I.S. 8:28). Sean cuales fueran los hechos detrás de los alternativos recuentos (todos igualmente míticos), la ocupación de la Sorbonne y la huelga general ilegal en toda la nación, con la fuerza de diez millones de personas, estaban en perfecto acuerdo con la doctrina situacionista. En resumen, 1968 fue una revolución situacionista independientemente de la responsabilidad o la intención.

13. Jonathan Crargy argumenta en contra de este juicio, afirmando que, de hecho, hemos entrado a una era en la cual nuevas redes de poder eclipsaron las del espectáculo, tanto estructural como cualitativamente. Donde Crary ve un eclipse yo entreveo una abstracta consolidación, sin embargo no es mi intención adentrarme aquí en esta cuestión, y el hecho de que registre nuestra diferencia no debería distraer del excelente análisis concluyente de Crary sobre la resistencia y el colapso fisiológicos. Véase Jonathan Crary, «Eclipse of the Spectacle », in : Brian Wallis (ed.), Art after Modernism: Rethinking Representation, Nueva York: Museum of Contemporary Art, 1984, p. 283-294.

14. Guy-Ernest Debord y Asger Jorn, Mémories, París: Internationale Situationniste, 1959, s.p.; edición facsimilar París: Les Belles Lettres, 1993.

15. Jean Baudrillard, Pour une critique de l'économie politique du signe, París: Gallimard, 1972, p. 199, 163.

16. Guy-Ernest Debord, La société du spectacle, París: Buchet-Chastel, 1967; The Society of the Spectacle. Trad. D. Nicholson-Smith. Nueva York: Zone Books, 1994, 71/35. La traducción samizdat de Nicholson-Smith de La société du spectacle está en prensa ahora. Sin embargo, voy a citar el 
texto de Debord por número de tesis, en vez de número de página, porque todavía hay muchas otras versiones en circulación.

17. No debería olvidarse que Debord era cineasta, ni tampoco debería pasarse por alto spéculer en su sentido económico. Este juego de palabras es explotado en el film casi contemporáneo de Alfred Hitchcock, La ventana indiscreta, en donde la cuestión en juego tanto en el voyeurismo de los personajes, como en sus discusiones del mercado de valores, es la ilegal y arriesgada speculation.

18. Guy-Ernest Debord, op. cit., páginas 34, 158.

19. Guy-Ernest Debord, op. cit., páginas 18, 24, 18, 187.

20. Guy-Ernest Debord, op. cit., páginas 16, 216, 13; Potlach, p. 29; Société, 30.

21. Por supuesto, León Trotsky escribió sobre la condición de la "vida cotidiana », y este concepto es un elemento importante de la cultura eslava (cf. Svetlana Boym, Common Places: Everyday life in Russia, Cambridge: Harvard University Press). La influencia cercana para los situacionistas fue, sin embargo, la crítica de Henri Lefebvre de «la vie quotidienne " [la vida cotidiana]. Lefebvre y Debord colaboraron a finales de los 50 y a principios de los 60, aunque los derechos de propiedad intelectual fueron subsecuentemente dirimidos con una ferocidad sorprendente para los supuestos defensores del plagio. Desde entonces, los análisis semejantes se han vuelto un poco más familiares; por ejemplo, los argumentos de Michel de Certeau en obras como Arts de faire [traducida como La invención de lo cotidiano. Artes de hacer], están tan en deuda con Debord como con Lefebvre; su famoso bricoleur es el hijo natural del antropólogo estructural de Lévi-Strauss con un situacionista descarriado. Menos conocido es el análisis hecho por Boris Arvatov, quien en 1925 puso su atención constructivista en el uso de objetos de la vida cotidiana por parte del consumidor. Como Debord, Arvatov imagina un mundo transformado porque, en lugar de seguir hábitos establecidos sin pensar, « la burguesía entró en contacto activo y creativo con el mundo de las Cosas» («Everyday Life and the Culture of the Thing. Toward the Formulation of the Question». Trad. C. Kiaer, October 81, verano 1997, p. 123). Donde Debord se enfoca en el potencial progresista de los consumidores activos, Arvatov desplaza la agencia hacia los objetos, distinguiendo entre el objeto activo (socialista) y el pasivo (capitalista), el cual es « algo acabado, fijo, estático, y, en consecuencia, muerto » (p. 122). Pese a la similitud retórica y metodológica, en definitiva Arvatov contrasta con Debord; con una conclusión que hubiera horrorizado a los situacionistas, Arvatov ve un mundo totalizador y jerárquico en el cual los objetos imponen sistemáticamente un cierto orden progresivo en el mundo. Más aún, su constructivismo es evidente, incluso en sus escritos sobre la vida cotidiana -por más que valora los objetos flexibles con una multiplicidad de usos (cf. p. 126), el uso sigue siendo primordial-. Con un pensamiento firmemente arraigado en Bataille, Debord y Baudrillard reaccionan contra un utilitarismo semejante.

Con un enfoque en la producción, vale la pena comparar el argumento de Baudrillard en La société de consommation [La sociedad de consumo] con el de Debord; el consumo moderno, argumenta Baudrillard, al navegar el «sistema de objetos", constituye una forma de trabajo como la que antes sólo se requería para la producción. De manera similar, Debord escribe: «la innovación siempre está presente en el proceso de producción de las cosas. Esto no es cierto sobre el consumo, que siempre es tan sólo más de lo mismo » (Société, p. 156). Como vamos a ver, Debord trata de discutir el consumo en términos de las continuas y siempre presentes innovaciones de la producción. Véase Jean Baudrillard, La société de consommation: ses mythes, ses structures, París: Denoël, 1970; La sociedad de consumo. Sus mitos, sus estructuras. Trad. A. Bixio. Madrid: Siglo XXI, 2009.

22. Guy-Ernest Debord, Société, p. 151.

23. Guy-Ernest Debord, op. cit., p. 120.

24. Para una elaboración del término bricoleur, alguien que comercia en tácticas más que en estrategias, véase Michel de Certeau, sobre «valerse de » (en el capítulo 3 de La invención de lo 
cotidiano). Claude Lévi-Strauss describe al bricoleur como alguien que utiliza «medios desviados por comparación con los del hombre de arte " (Lévi-Strauss, El pensamiento salvaje. Bogotá: FCE, 1997, p. 35). Reconociendo la naturaleza dada e ineludible de toda situación, para luego ignorar el uso previsto o la implementación habitual de sus elementos y violar sus obvias reglas de aplicación, el bricoleur de Lévi-Strauss, de manera creativa, contingente y provisional, usa mal esos elementos, pues « la regla de su juego es siempre la de arreglárselas con 'lo que uno tenga' » de modo de obtener «resultados brillantes e imprevistos» (p. 36). Este mismo impulso puede verse en el argumento de Baudrillard contra la ideología de la utilidad y el estatus del valor de « uso » en el pensamiento marxista, los cuales han « contribuido a la mitología (...) que hace pasar la relación del individuo con los objetos concebidos como valor de uso por una relación concreta y objetiva, 'natural' en suma, entre la necesidad propia del hombre y la función propia del objeto ». Jean Baudrillard, Crítica de la economía política del signo, México: Siglo XXI, 1979, p. 154.

Sin embargo, a diferencia del bricoleur de Lévi-Strauss, el situacionista es más proclive al influjo del «modo de la contigencia » exterior, ya sea "al nivel de la ocasión » o « de la destinación » (Lévi-Strauss, p. 50) y, de hecho, siempre está buscando "el otro mensaje, que podría serle arrancado a un interlocutor, a pesar de su resistencia a declarar acerca de cuestiones cuyas respuestas no han sido repetidas de antemano " (Lévi-Strauss, p. 40). En tanto científico de la excepción y de lo singularmente concreto, el bricoleur situacionista tiene más de patafísico (y, encima de todo, probablemente de economista con licencia general). La resonancia situacionista del énfasis de Lévi-Strauss en el « diálogo » en el cual se involucra el bricoleur será aclarada.

25. Guy-Ernest Debord, Société, p. 178.

26. I.S., 8, p. 38; Guy-Ernest Debord, Société, p. 116; cf. páginas 62, 187, 178; $112 ; 115$.

27. Mustapha Khayati, "Captive Words: Preface to a Situacionist Dictionary ", Situationist International Anthology. Ed. y trad. K. Knabb, Berkeley: Bureau of Public Secrets, 1981, p. 175. [« Las palabras cautivas (Prefacio para un diccionario situacionista)». Trad. L. Navarro Monedero, in: Gonçal Mayos (ed.), Filosofía para indignados. Textos situacionistas, Barcelona: RBA Libros, 2013, p. 195]. No debería pasarse por alto la metafísica romántica de la presencia sugerida en el uso frecuente de adjetivos como «real», "verdadero", " auténtico», " genuino", " directo", «transparente», y así sucesivamente, por parte de Debord. En efecto, en la escritura situacionista hay obviamente mucho que atrae a la crítica, no poco de lo cual se encuentra en su dudosa política sexual. Lo mejor de la obra situacionista -el análisis agudo y resoluto que se niega a evitar una autocrítica igualmente rigorosa- se opaca y decae con su repetida tendencia a derivar hacia la nostalgia elegíaca y al romanticismo sentimental. Como escribiera Thomas Pynchon, no hay nada peor que «un surrealista sentimental». Thomas Pynchon, Gravity's Rainbow, Nueva York: Penguin, 1973, p. 696.

Sin embargo, no deberíamos confundirnos con el uso ideosincrático de ciertas palabras como termes de métier por parte de Debord. Por ejemplo, como argumentaré en el tercer capítulo [se refiere al capítulo 3 de Reading the Illegible], «transparencia » es una metáfora cargada de sentido ideológico. Para Debord, insisto enfáticamente, «transparencia» contrasta no tanto con opacidad o ilegibilidad como con el efecto reflejo-speculum (« espejo » en latín) del espectáculo. Una vez más, sus preocupaciones son miméticas; su lenguaje continuamente valora la encarnación por sobre y en contra de la re-presentación.

28. I.S., 4, p. 37. Desde el punto de vista del objeto situacionista, (es evidente que la fusión de actividades estéticas y revolucionarias en la vida cotidiana, técnicamente obvia la posibilidad de « obras de arte » situacionistas), este ideal repite el sueño familiar del modernismo radical: no re producción espectacular, sino producción, no representación, sino actuación directa. «El poema debe ser, no significar »; o, en las palabras de Stein: « composición como explicación ». Los lemas podrían proliferar, pero: « El objeto es tomar posesión efectiva de la comunidad de diálogo y de la relación lúdica con el tiempo, las cuales hasta ahora han sido meramente representadas en las obras de poetas y artistas ». Cf. Guy-Ernest Debord, Société, p. 187. 
29. Bruce Andrews, Paradise, p. 54.

30. Jean-Marie Apostolidès, « $\mathrm{Du}$ surréalisme à l'Internacional Situationniste: la question de l'image ", Modern Language Notes 105, 1990, p. 729.

31. Guy-Ernest Debord, « All the King's Men », in : K. Knabb, op. cit., p. 144 [Mayos, op. cit. , p. 120].

32. Guy-Ernest Debord, op. cit., in : K. Knabb, op. cit., p. 114, p. 117, p. 114 [Mayos, op. cit., p. 120, p. 129, p. 120].

33. Guy-Ernest, op. cit., p. 114 [p. 120 y p. 121].

34. Guy-Ernest Debord, Société, p. 121, p. 122, 131; cf. p. 200.

35. Citado en Julia Kristeva, Revolution in poetic language. Trad. M. Waller. Nueva York: Columbia University Press, p. 256. La obstinación de la práctica paragramática -la terca inocencia con la cual el patafísico da uso a sus herramientas- huele un poco a lo « obtuso » de Barthes: « se abre al infinito del lenguaje, resulta limitado para la razón analítica; es de la misma raza de los juegos de palabras, de las bromas, de los gastos inútiles (...) pertenece a la esfera del carnaval » [Roland Barthes, Lo obvio y lo obtuso. Imágenes, gestos, voces, Barcelona: Paidós, 1986, p. 59].

36. Sobre la figura del laberinto situacionista, véase Vincent Kaufman, « Angels of Purity ». Trad. J. Goodman. October 79, invierno 1997, p. 62.

37. Guy-Ernest Debord, Société, p. 208; Conde de Lautréamont (Isidore Ducasse), Poésies, Londres: Allison and Busby, 1978, p. 68. La apropiación fue, para los situacionistas, una de las salidas del lío en que se metieron al establecer que, como Escila y Caribdis, tradición e innovación debían ser igualmente evitadas. Sin embargo, incluso más allá del plagio de contenido inspirado en Lautréamont, el principio del détournement puede ser leído a nivel de la sintaxis quiásmica de Debord: una estructura gramatical repetida y luego invertida, típicamente por medio de una inversión de la lógica del genitivo. Así, con el hegelianismo característico de este "estilo insurreccional », la gramática de las oraciones mismas de Debord détourne sus propias frases. (cf. Guy-Ernest Debord, op. cit., p. 206).

38. Con sus injertos e inversiones trastornadoras que llevan a un tercer término productivo, los détournements tienen más que un leve parecido con las déconstructions de Derrida. Para más dtelalles sobre collage y deconstrucción, véase Gregory Ulmer, « The Object of Post-Criticism », in : H. Foster (ed.), The Anti-Aesthetic: Essays on Postmodern Culture, Seatle: Bay, 1983.

39. Grupo $\mu$, «Collages », Revue d'esthétique, $\mathrm{n}^{\circ}$ 3-4, París: Union Générale d’Éditions, 1978, p. 34-35.

40. Marjorie Perloff, The Futurist Moment, Chicago, University of Chicago Press, p. 75.

41. Víctor Shklovski, "Art as Technique ", Russian Formalist Criticism: Four Essays. Trad. L. T. Lemon y M. J. Reis. Lincoln: University of Nebraska Press, 1965, p. 12 [" El arte como artificio », in : T. Todorov (ed.), Teoría de la literatura de los formalistas rusos. Trad. A. M. Nethol, México: Siglo XXI, 1970, p. 60].

42. 0 , como podría haber sido desvié con un corrimiento ( $s d v i g)$ de sentido en el vocabulario de los situacionistas: soûler, épave, veillée, plagiat (emborracharse, restos del naufragio, velada, plagio).

43. Se trata, por supuesto, de una expresión corriente -el mismo año que Jorn había desviée esta pintura Jacques Robert publicaba su Paris la nuit-, pero el emblemático libro del mismo título publicado en 1933 por Brassaï debería haber sido un punto de referencia inevitable para Jorn.

44. Guy-Ernest Debord, Société, p. 53, p. 24.

45. Claire Gilman comienza su artículo sobre Jorn con la misma observación, aunque minimiza sus consecuencias. Su argumento se opone a mi lectura en varios puntos, y vale la pena consultarlo para una valoración muy diferente del éxito de Jorn. Si bien no veo la necesidad de cuestionarlo punto por punto, el origen de nuestro desacuerdo debería quedar claro en mis argumentos a lo largo de este capítulo. Una observación tangencial: aunque Gilman articula su análisis en términos extrañamente sexuales, reiterando la «impotencia » de Jorn, nunca hace explícita la naturaleza eyaculatoria de las manchas en Paris by Night, las cuales describe 
bellamente en forma de «delgadas goteaduras blancas fijadas en la superficie como crema de leche ». Claire Gilman, « Asger Jorn's Avant-Garde Archives », October 79, invierno de 1997, p. 37. 46. Guy-Ernest Debord y Gil J. Wolman, « Mode d'emploi du détournement », in : G. Barreby( ed.), Les lèvres nues 8, mayo de 1956. Documents relatifs à la formation de l'Internationnale Situationniste, París: Allia, 1985, p. 302. "Methods of Detournement». Trad. y ed. K. Knabb, op.cit., p. 8 [«Métodos de tergiversación». Trad. Industrias Mikuerpo, disponible en <http:// serbal.pntic.mec.es/ cmunoz11/debord.html>, página consultada el 03/08/2017.]

47. Sobre el problema de los títulos de Jorn, véase Guy Atkins y Troels Andersen, Asger Jorn: The Final Years (1965-1973), Londres: Lund Humphries, 1980, p. 66.

48. Guy Atkins, op. cit., p. 143.

49. [Aquí, Dworkin transforma creativamente, o -en sus términos- desvía el refrán «A bird in the hand is worth two in the bush » (literalmente: un pájaro en la mano vale más que dos en un arbusto) para aludir al uso de una sola mano, por parte de Jorn, en lugar de dos, cuando escribe: "A hand in the bird, in other words, is worth pushing the two ». Lamentablemente, este juego de palabras no es del todo traducible al español.]

50. Greil Marcus sostiene que Mémoires fue concebido a finales de 1957, pero no fue publicado hasta 1959 (véase Greil Marcus, «Guy Debord's Mémoires: A Situationist Primer », in : Elisabeth Sussman (ed.), On the passage of a few people through a rather brief moment in time: the Situationist International, 1957-1972, Cambridge: MIT Press, 1989, p. 126). La edición facsimilar de Belles Lettres del año 1993 fecha la primera edición en 1958, lo cual parece ser corroborado por el prefacio de Debord a dicha edición; tanto Crow como Atkins dan 1959 como fecha de la composición y de la publicación (véase Thomas Crow, The Rise of the Sixties, Nueva York: Abrams, 1996, p. 52; Atkins y Andersen, op. cit., p. 66). Sea cual fuere el caso, el punto es que estos libros emergen del mismo momento de actividad que también dio luz a la naciente Internationale Situationniste.

51. Guy-Ernest Debord, Société, p. 138.

52. Una vez más hay cierta discrepancia sobre los detalles; Atkins registra el período de composición como un día, y una noticia en la Architectural Review lo reduce a « una sola tarde ». Marcus, sin embargo, sostiene que el tiempo de realización fueron cuarenta y ocho horas, en lugar de veinticuatro (Greil Marcus, Lipstick Traces: A Secret History of the Twentieth Century, Cambridge: Harvard University Press, 1989, p. 455; no obstante, olvida citar la fuente que lo autoriza), y Len Bracken cronometra juiciosamente que fue « un fin de semana » (Len Bracken, Guy Debord: Revolutionary, Venice, California: Feral House, 1997, p. 76). En todo caso, seguramente tampoco es de poca importancia que la "duración media de una deriva sea de una jornada » (Guy-Ernest Debord, « Théorie de la dérive », Les levres nues 9, noviembre de 1956, p. 51 ["Teoría de la deriva », Internacional situacionista, vol. I: La realización del arte, Madrid: Literatura Gris, 1999, disponible en <http:// www.ugr.es/ silvia/documentos\%20colgados/IDEA/teoria\%20de\%20la\%20deriva.pdf>; trad. mod.] Para más información sobre el concepto situacionista de la dérive, véase más abajo.

53. Literalmente, "tiene una cara de papel maché »; en sentido figurado, "tiene un aspecto demacrado ».

54. [Sólo « virutas » en español, pero también « afeitadas » en inglés.]

55. Kaufman nota con astucia que los situacionistas emergieron « en un momento en el cual ir a la deriva a merced de los significantes se estaba volviendo ubicuo». Vincent Kaufman, « Angels of Purity ». Trad. J. Goodman, October 79, invierno de 1997, p. 60.

56. Guy-Ernest Debord, "Théorie de la dérive ", in: Les lèvres nues 9, noviembre de 1956 ; in: G. Barreby (ed.), op. cit., p. 312; « Theory of the Dérive », in : K. Knabb (ed.), op. cit., p. 50 [« Teoría de la deriva ", véase nota 52 más arriba].

57. Guy-Ernest Debord, op. cit. 
58. Guy-Ernest Debord, op. cit. [trad. mod.]

59. La ingenuidad desalentadora no es tanto la creencia de los situacionistas en que deambular borracho durante días era revolucionario -con la dérive agregando simplemente un sofisticado aire francés a los zigzagueos y tambaleos de un ebrio a lo largo y ancho de la vereda- sino nuestro olvido de que puede no serlo.

60. Greil Marcus, « Guy Debord's Mémoires: A Situationist Primer », op.cit., p. 128.

61. Len Bracken, Guy Debord: Revolutionary, Venice, CA: Feral House, 1997, p. 29.

62. «Se come bien ahí. Y se encuentra a un montón de buena gente. Algunos escritores, algunos artistas, más o menos empobrecidos y, todos ellos, llenos de ilusiones » (G-E. Debord y A. Jorn, Mémoires). « En la terraza del café » es uno de los fragmentos del collage de Fin de Copenhague; hice mi recuento de la vida situacionista en los bares a partir de fotografías, además de entrevistas y documentos citados en Marcus, Bracken y la autobiografía de Debord (Panegyrique), así como también en La tribu (París: Éditions Allia, 1998) de Jean-Michel Mansion y a partir de las fotografías de Ed van der Eksken.

63. Guy-Ernest Debord y Gil Wollman, « Mode d'emploi ». Las chorreaduras de Jorn bien pueden recordar también el goteo de imitación en la caligrafía del letrero de Le Tonneau d'Or, uno de los bares frecuentados por Debord y su camarilla.

64. Stewart Home, The Assault on Culture: Utopian Currents from Lettrisme to Class War, Londres: Aporia Press y Unpopular Books, 1988, p. 30.

65. Guy-Ernest Debord, Panegyrique: Tome premier, París: Éditions Gérard Lebovici, 1989, p. 46; Panegyric. Trad. J. Brook. Nueva York: Verso, 1991, p. 35.

66. Guy-Ernest Debord, op. cit. p. 43 / 33.

67. Guy-Ernest Debord, op. cit. p. 44 / 34.

68. Citado en Grey Marcus, Lipstick Traces, op.cit., p. 352.

69. Por un lado, como he sugerido, la paragramática situacionista implica un "mal uso » antiutilitarista aprendido directamente de Bataille. Esta tendencia puede verse a nivel teórico por ejemplo en los repetidos llamados al antifuncionalismo del MIBI- así como también a nivel de la enunciación. Cuando Jorn describe sus modificaciones como «pintura sacrificada " alude a Bataille, tal como lo hace la referencia a « The Northwest Passage » en Mémoires. Esta trayectoria no es tan solo una mítica línea de fuga, el curso de la dérive más definitiva, sino que " noroeste » también evoca "los grandes tótems indios de Norteamérica " y a los chinook, que le dieron a Debord el título de su diario, Potlach. En contraste con la economía restringida favorecida por los surrealistas, según Apostolidès, la IS « participe égalment d'une économie générale des conduites basées davantage sur le modèle du don/contre don que sur l'échange marchand " [participa igualmente de una economía general de conductas basadas más en el modelo del don/contra don que en el intercambio mercantil] (Apostolidès, op.cit., p. 748). Voy a discutir la naturaleza de la «economía general» de Bataille en mayor profundidad en el capítulo 4, pero por ahora sólo quiero señalar simplemente, con todo mi respeto por Apostolidès, que si los situacionistas realizan ciertos sacrificios antiutilitaristas como parte de sus détournements, estos siempre están al servicio de una economía restringida que recupera sus « mal usos » con objetivos productivos específicos. Jorn, por ejemplo, concibe sus modificaciones en términos explícitamente económicos (restringidos): obras « devaluadas » que han sido « reinvertidas » para participar en un intercambio simbólico en vez de simplemente eliminadas por completo del sistema.

70. Si bien no se oponía directamente a otras drogas fuera del alcohol, en lo personal, Debord no estaba impresionado por ninguna de ellas, aunque éther, absinthe, marihuana, y láudano hacen su aparición en Mémoires, esta última explícitamente relacionada con la « bebida »: «Et Thomas de Quincey buvant / L'opium poison doux et chaste / À sa pauvre Anne allait rêvant » [Y Thomas de Quincey bebiendo / El opio veneno dulce y casto / Iba soñando a su pobre Anne].

71. Panegyrique, p. 49 / 37. En Les chants de Maldoror, esta línea aparece al final de la sección sobre el excremento del escarabajo en el Canto 5: « El escarabajo, bello como el temblor de las manos en 
el alcoholismo, desapareció por el horizonte " [Comte de Lautréamont, Los cantos de Maldoror. L. M. Pérez-Boite (ed.), Santa Clara, Cuba: Ediciones Sed de Belleza, 2006, p. 139.]

72. [En francés pression y en inglés draft/draught significan tanto corriente de aire como cerveza tirada o de barril, lo que permite un juego de palabras entre corrientes de aire y de cerveza que se pierde en español.]

73. En Mémoires, Debord resalta el ritmo con la línea: « La fin, on l'a devinée » [el final, lo hemos adivinado].

74. Cf. Guy-Ernest Debord, Panegyrique, p. 35-36.

75. En términos situacionistas, este sería un tiempo desalienado, anti espectacular. En un punto, Debord define al espectáculo mismo como "en efecto, una falsa conciencia del tiempo »; en contraste, el tiempo anárquico debe caracterizarse por una permanente inminencia (véase Société , p. 158, p. 94).

76. Guy-Ernest Debord, Panegyrique, p. 45 / 35.

77. «Muchas personas me encontrarán, sin duda, demasiado indulgente. 'Usted absuelve la borrachera e idealiza el vicio'. Confieso que ante los beneficios [del vino, muchas veces] carezco de coraje para contar los daños ». Charles Baudelaire, Paraísos artificiales. Trad. L. Echávarri, disponible en <https://www.guao.org/sites/default/files/biblioteca/Paraisos\%20artificiales\% 20.pdf >, consultado el 26/5/2017. El alcoholismo contradice las mejores aspiraciones políticas de Debord a una revolución de la vida cotidiana. En sus repeticiones y compulsiones, la adicción (e incluyo aquí el café matinal de los académicos -que ahora bebo a sorbos-, entre frase y frase) es un régimen esencialmente fascista (véase Deleuze y Guattari, op. cit.).

78. Gilles Deleuze, Lógica del sentido. Trad. M. Morey, Escuela de Filosofía Universidad ARCIS, p. 114, disponible en <http://www.uruguaypiensa.org.uy/imgnoticias/588.pdf>, consultado el $7 / 4 / 2017$.

79. Gilles Deleuze, op. cit., p. 115.

80. I.S. 3: 16. Esta valorización, según los situacionistas, también se refiere al calendario condenado al fracaso de la vanguardia histórica. Por definición, una vanguardia que se precie de su nombre no puede permitirse mirar órficamente hacia atrás, pero sus miembros tampoco pueden flaquear e imaginarse sobreviviendo en el futuro: son, verdaderamente, les enfants perdus. En pocas palabras: « las vanguardias sólo tienen un tiempo ». Guy-Ernest Debord, In girum imus nocte et consumimur igni. Trad. L. Forsyth, Londres: Pelagian, 1991, p. 63.

81. Gilles Deleuze, Lógica, op.cit., p. 115; Malcolm Lowry, Under the Volcano, Nueva York: New American Library, 1971, p. 364, p. 369 y en las páginas siguientes.

82. Gilles Deleuze, Lógica, op. cit. p. 116.

83. Guy-Ernest Debord, Société, p. 87, p. 141.

84. Guy-Ernest Debord, op. cit., p. 163.

85. Guy-Ernest Debord, op. cit., páginas 126, 149, 147, 145.

86. Arthur Rimbaud, Saison, p. 104 [p. 83].

\section{AUTHORS}

\section{CRAIG DWORKIN}

University of Utah 